\title{
Psoriasis. Diagnostic and therapeutic recommendations of the Polish Dermatological Society. Part 2
}

\section{Łuszczyca. Rekomendacje diagnostyczno-terapeutyczne Polskiego Towarzystwa Dermatologicznego. Część 2}

\author{
Adam Reich', Zygmunt Adamski², Grażyna Chodorowska ${ }^{3}$, Andrzej Kaszuba ${ }^{4}$, Dorota Krasowska ${ }^{3}$, \\ Aleksandra Lesiak ${ }^{4}$, Joanna Maj ${ }^{5}$, Joanna Narbutt ${ }^{4}$, Agnieszka J. Osmola-Mańkowska², \\ Agnieszka Owczarczyk-Saczonek ${ }^{6}$, Witold Owczarek ${ }^{7}$, Waldemar J. Placek ${ }^{6}$, Lidia Rudnicka ${ }^{8}$, Jacek Szepietowski ${ }^{5}$
}

\section{'Department of Dermatology, University of Rzeszow, Poland}

2Department of Dermatology, Poznan University of Medical Sciences, Poland

${ }^{3}$ Department of Dermatology, Venereology and Paediatric Dermatology, Medical University of Lublin, Poland

${ }^{4}$ Department of Dermatology, Paediatric and Oncologic Dermatology, Medical University of Lodz, Poland

${ }^{5}$ Department of Dermatology, Venereology and Allergology, Wroclaw Medical University, Poland

${ }^{6}$ Department of Dermatology, Sexually Transmitted Diseases and Clinical Immunology, University of Warmia and Mazury, Olsztyn, Poland

7Department of Dermatology, Military Institute of Medicine, Warsaw, Poland

${ }^{8}$ Department of Dermatology, Medical University of Warsaw, Poland

'Zakład i Klinika Dermatologii, Uniwersytet Rzeszowski, Polska

2Katedra i Klinika Dermatologii, Uniwersytet Medyczny w Poznaniu, Polska

${ }^{3}$ Katedra i Klinika Dermatologii, Wenerologii i Dermatologii Dziecięcej, Uniwersytet Medyczny w Lublinie, Polska

${ }^{4}$ Katedra i Klinika Dermatologii, Dermatologii Dziecięcej i Onkologicznej, Uniwersytet Medyczny w Łodzi, Polska

${ }^{5}$ Katedra i Klinika Dermatologii, Wenerologii i Alergologii, Uniwersytet Medyczny we Wrocławiu, Polska

${ }^{6}$ Katedra i Klinika Dermatologii, Chorób Przenoszonych Drogą Płciową i Immunologii, Uniwersytet Warmińsko-Mazurski w Olsztynie, Polska

${ }^{7}$ Klinika Dermatologii, Wojskowy Instytut Medyczny w Warszawie, Polska

${ }^{8}$ Katedra i Klinika Dermatologiczna, Warszawski Uniwersytet Medyczny, Polska

\section{CORRESPONDING AUTHOR/ ADRES DO KORESPONDENCJI: prof. Adam Reich Zakład i Klinika Dermatologii Uniwersytet Rzeszowski ul. Szopena 2 35-055 Rzeszów, Polska tel.: +48605076 722 e-mail: adi_medicalis@go2.pl}

\begin{abstract}
Psoriasis is one of the most common chronic inflammatory dermatoses. We present the second part of the diagnostic and therapeutic guidelines on psoriasis. The second part discusses the principles of treatment of plaque psoriasis, with a particular emphasis on systemic drugs. The guidelines have been updated to take into consideration new therapies which have recently been approved in Poland, ongoing improvements in the efficacy of available therapeutic methods, and changing needs of patients. We hope that the current guidelines will assist physicians in making diagnostic and therapeutic decisions, and contribute to the improvement of medical care provided to patients with psoriasis.
\end{abstract}

\section{STRESZCZENIE}

Łuszczyca jest jedną z najczęstszych przewlekłych dermatoz zapalnych. W drugiej części rekomendacji diagnostyczno-terapeutycznych poświęconych łuszczycy omówione zostały zasady leczenia łuszczycy plackowatej ze szczególnym uwzględnieniem leków stosowanych ogólnie. Uaktualnienie wytycznych zostało podyktowane dostępem do nowych terapii, które ostatnio zostały zarejestrowane również w Polsce, coraz większą efektywnością dostępnych metod leczenia, a także 
zmieniającymi się potrzebami pacjentów. Mamy nadzieję, że aktualne wytyczne pomogą lekarzom w podejmowaniu decyzji diagnostyczno-terapeutycznych oraz przyczynią się do poprawy opieki medycznej nad chorymi na łuszczycę.

Key words: diagnostics, treatment, psoriasis, guidelines.

Słowa kluczowe: diagnostyka, leczenie, łuszczyca, wytyczne.

\section{INTRODUCTION}

We present the second part of the diagnostic and therapeutic guidelines on psoriasis. The second part discusses the principles of treatment of plaque psoriasis, with a particular emphasis on systemic drugs. The second part of the guidelines constitutes an integral whole with the first part which addresses the general principles of diagnostic management, prevention of cardiovascular complications, therapeutic goals, and selected specific forms of psoriasis. We hope that the current guidelines will assist physicians in making diagnostic and therapeutic decisions, and contribute to the improvement of medical care provided to patients with psoriasis.

\section{TOPICAL THERAPY (TOPICAL THERAPY OF MILD PSORIASIS)}

Psoriatic lesions of low severity are treated primarily with topical agents. Topical drugs should also be used in patients with moderate to severe psoriasis as an adjunct to phototherapy or systemic treatment. The therapeutic option to consider at the start of treatment of psoriatic lesions are keratolytic agents (topical formulations containing urea, salicylic acid, lactic acid and/or sulphur, usually in the form of compounded drugs) in order to remove overlying layers of scale which impair the penetration of reducing and anti-inflammatory drugs into the lesions. Patients with psoriasis can also benefit from emollients as an adjunct therapy, based on their ability to reduce the severity of scaling and pruritus.

The most widely used topical agent, especially in the treatment of localised skin lesions, is calcipotriol in combination with betamethasone dipropionate, mainly because of the synergistic effect of both agents against psoriasis, high efficacy, rapid onset of action, and low risk of skin irritation. It needs to be noted that calcipotriol has the capacity to reverse, at least partially, the atrophogenic effect of betamethasone [1]. Based on the study results, combination therapy with calcipotriol and betamethasone dipropionate is the most effective topical treatment modality in psori-

\section{WPROWADZENIE}

Oddajemy do druku drugą część wytycznych diagnostyczno-terapeutycznych poświęconych łuszczycy. W tej części omówione zostały zasady leczenia łuszczycy plackowatej ze szczególnym uwzględnieniem leków stosowanych ogólnie. Druga część wytycznych stanowi integralną całość z częścią pierwszą, w której przedstawiono ogólne zasady postępowania diagnostycznego, profilaktyki powikłań sercowo-naczyniowych, cele terapeutyczne oraz niektóre szczególne postaci łuszczycy. Mamy nadzieję, że aktualne wytyczne pomogą lekarzom w podejmowaniu decyzji diagnostyczno-terapeutycznych oraz przyczynią się do poprawy opieki medycznej nad chorymi na łuszczycę.

\section{LECZENIE MIEJSCOWE (LECZENIE MIEJSCOWE SKÓRY GŁADKIEJ)}

W leczeniu zmian łuszczycowych o niewielkim nasileniu zastosowanie znajdują przede wszystkim leki stosowane zewnętrznie. Leki stosowane zewnętrznie powinny być także stosowane w przypadku łuszczycy umiarkowanej do ciężkiej jako uzupełnienie fototerapii lub leczenia ogólnego. Na początku leczenia zmian łuszczycowych często wskazane jest zastosowanie środków keratolitycznych (preparaty miejscowe zawierające mocznik, kwas salicylowy, kwas mlekowy i/lub siarkę, zazwyczaj w formie leków recepturowych) w celu usunięcia nawarstwień łusek pokrywających zmiany łuszczycowe, które utrudniają przenikanie leków o działaniu redukującym i przeciwzapalnym w głąb zmian chorobowych. U chorych na łuszczycę korzystne może być także wspomagające stosowanie emolientów, które zmniejszają nasilenie łuszczenia i świądu.

W terapii miejscowej, zwłaszcza ograniczonych ognisk chorobowych, najszerzej stosuje się kalcypotriol $\mathrm{w}$ połączeniu $\mathrm{z}$ dipropionianem betametazonu, głównie ze względu na synergizm działania przeciwłuszczycowego, dużą skuteczność, szybki początek działania i niskie ryzyko podrażnień skóry. Warto podkreślić, że kalcypotriol może przynajmniej 
asis [2]. Moreover, the available data indicate that the combination of calcipotriol and betamethasone may be used for long-term treatment (efficacy and safety were evaluated for 52 weeks), without a significant increase in the risk of adverse reactions [3]. In patients requiring treatment of many weeks' duration, intermittent therapy (e.g. twice a week including the so called pro-active therapy) should be considered.

The combination of calcipotriol and betamethasone is available in a gel or ointment formulation, and recently also in the form of foam. Because of its physicochemical properties, the foam formulation has higher therapeutic efficacy compared to the gel or ointment formulation [4].

Vitamin $\mathrm{D}_{3}$ derivatives (e.g. tacalcitol, calcipotriol) can also be used in monotherapy. They are characterised by high efficacy demonstrated in clinical trials, good cosmetic properties and a favourable safety profile, though their widespread use is limited by a relatively high price, inferior efficacy to combined drugs, and a delayed onset of action (therapeutic effects are typically seen only after 6-8 weeks of treatment). Vitamin $\mathrm{D}_{3}$ analogues should be used with caution in young children (<12 years of age), in patients with disorders of calcium and phosphate metabolism, liver or kidney failure, and in breast-feeding women. Vitamin $\mathrm{D}_{3}$ derivatives should not be combined with keratolytic agents containing salicylic or lactic acids, as both calcipotriol and tacalcitol become deactivated in an acidic environment. In patients receiving combination treatment with vitamin $\mathrm{D}_{3}$ derivatives and phototherapy, UV irradiation treatment should be provided first, followed by the application of a topical drug.

Glucocorticosteroids are a widely used therapeutic option in the treatment of psoriatic skin lesions because of their fast action, high efficacy and good cosmetic properties. However, long-term application of glucoccorticosteroids on the skin is associated with a significant risk of persistent localised complications including skin atrophy and telangiectasia. Also, the withdrawal of corticosteroids often leads to a rapid recurrence of psoriasis, and even the so-called rebound effect, i.e. development of psoriatic lesions of greater severity (including pustules) than before the onset of therapy. Consequently, topical glucocorticosteroids are only recommended for short-term treatment, and they are usually prescribed at the start of therapy to achieve a more rapid remission of psoriatic lesions. Clobetasol propionate, the most potent topical glucocorticosteroid, is indicated only for refractory psoriatic lesions which do not respond to other topical therapies.

Dithranol is mostly used in the hospital setting at increasing concentrations from $0.05 \%$ to $2-3 \%$ once or twice a day for 2-4 hours (or for a longer period częściowo odwracać atrofogenne działanie betametazonu [1]. Wyniki badań wskazują, że połączenie kalcypotriolu z dipropionianem betametazonu jest najskuteczniejszą opcją leczenia miejscowego łuszczycy [2]. Ponadto dostępne dane wskazują, że połączenie kalcypotriolu z betametazonem może być stosowane długotrwale (skuteczność i bezpieczeństwo oceniano przez 52 tygodnie) bez istotnego wzrostu ryzyka wystąpienia działań niepożądanych [3]. W przypadku wielotygodniowej terapii zaleca się rozważenie leczenia z przerwami (na przykład 2 razy w tygodniu, w tym tzw. terapii proaktywnej).

Preparaty zawierające kalcypotriol z betametazonem są dostępne $\mathrm{w}$ formie żelu, maści, a od niedawna także $\mathrm{w}$ formie piany. Z uwagi na właściwości fizykochemiczne forma piany zapewnia większą skuteczność w porównaniu z preparatem żelowym czy maściowym [4].

Pochodne witaminy $\mathrm{D}_{3}$ (np. takalcytol, kalcypotriol) mogą być także stosowane w monoterapii. Cechują się skutecznością potwierdzoną w badaniach klinicznych, dobrymi właściwościami kosmetycznymi oraz korzystnym profilem bezpieczeństwa, choć ograniczeniem ich szerszego zastosowania jest stosunkowo wysoka cena, mniejsza skuteczność niż preparatów łączonych, a także opóźniony początek działania (efekt terapeutyczny obserwowano zazwyczaj dopiero po 6-8 tygodniach leczenia). Analogi witaminy $\mathrm{D}_{3}$ należy stosować ostrożnie u małych dzieci (<12 lat), u pacjentów z zaburzeniami gospodarki wapniowo-fosforanowej, u chorych z niewydolnością wątroby lub nerek oraz u kobiet karmiących piersią. Pochodnych witaminy $\mathrm{D}_{3}$ nie należy łączyć z preparatami keratolitycznymi zawierającymi w składzie kwas salicylowy lub mlekowy, gdyż zarówno kalcypotriol, jak i takalcytol ulegają unieczynnieniu w środowisku kwaśnym. W przypadku łącznego stosowania pochodnych witaminy $\mathrm{D}_{3} \mathrm{i}$ fototerapii należy najpierw wykonać zabieg naświetlania UV, a dopiero później aplikować miejscowo preparat.

Glikokortykosteroidy są szeroko stosowane w leczeniu ognisk łuszczycy na skórze ze względu na szybkość działania, dużą skuteczność i dobre właściwości kosmetyczne. Długotrwałe stosowanie glikokortykosteroidów na skórę wiąże się jednak $\mathrm{z}$ istotnym ryzykiem wystąpienia trwałych powikłań miejscowych, takich jak zaniki skóry i teleangiektazje, a w chwili ich odstawienia często dochodzi do szybkiego nawrotu zmian łuszczycowych, a nawet do tzw. zjawiska z odbicia, czyli wysiewu zmian łuszczycowych o większym nasileniu (w tym krost) niż przed rozpoczęciem terapii. $Z$ tego powodu glikokortykosteroidy stosowane miejscowo są rekomendowane jako leczenie krótkotrwałe, zazwyczaj na początku terapii, w celu uzyskania szybszego ustąpienia zmian łuszczycowych. Stosowanie propionianu klobetazo- 
at lower concentrations). If higher drug concentrations $(0.5-3 \%)$ are used on an outpatient basis, the so-called "minutes therapy" can be used, with the drug administered at a high concentration from the beginning, but for a considerably shorter period (approximately 10-30 minutes). The drug has a reducing effect by inhibiting excessive proliferation of keratinocytes. An important benefit of the drug is that in a proportion of patients it is able to induce disease remission of many months' duration. Disadvantages of dithranol include its poor cosmetic properties. The drug may cause skin hyperpigmentation and stain clothes. In addition, dithranol has a characteristic odour which some patients may find unacceptable. Also, dithranol has a potential to irritate the skin and, for this reason, it should not be applied to skin folds, to the face (risk of conjunctival irritation and skin hyperpigmentation), and acutely inflamed lesions of plaque psoriasis.

Tazarotene is currently the only topical retinoid approved in Poland for the treatment of plaque psoriasis, though it has not been commercially available for a fairly long time. Tazarotene is associated with a lower improvement rate compared to other topical antipsoriatic agents. However, following the resolution of psoriatic lesions the period of remission appears to be longer than after treatment with topical glucocorticosteroids or vitamin $\mathrm{D}_{3}$ derivatives. In view of the fact that the drug is expensive and has a potential to cause skin irritation, it represents an alternative therapy which may be prescribed to patients unsuccessfully treated with other topical medications, with minor psoriatic lesions or as an add-on therapy to support other medical treatments.

Psoriasis can also be topically treated with tars, usually at concentrations in the range of $5-10 \%$. The currently available pharmacy formulation is pine tar (Pix liquidi Pini). In view of the carcinogenic potential shown in vitro and in animal studies, though not confirmed in humans, tars are now recognised as an alternative therapeutic modality, recommended only after other topical treatment options have been exhausted.

Calcineurin inhibitors (pimecrolimus, tacrolimus) are approved for the treatment of atopic dermatitis, but they can also be a valuable adjunct to the topical therapy of psoriasis, especially in the treatment of lesions on the face and in the genital area. Calcineurin inhibitors are also recommended in cases of inverse psoriasis, to be applied to the skin folds and flexural surfaces [5].

\section{PHOTOTHERAPY AND PHOTOCHEMOTHERAPY}

In view of its high efficacy and low number of serious adverse reactions, phototherapy is current- lu, najsilniejszego glikokortykosteroidu stosowanego miejscowo, jest zalecane jedynie w przypadku opornych ognisk łuszczycy, niereagujących na inne metody leczenia miejscowego.

Cygnolina jest zazwyczaj stosowana w warunkach szpitalnych we wzrastających stężeniach od 0,05\% do 2-3\% jednokrotnie lub dwukrotnie w ciągu dnia na 2-4 godziny (niższe stężenia mogą być pozostawiane na dłużej). W przypadku aplikowania wyższych stężeń leku (0,5-3\%) w warunkach ambulatoryjnych można wykorzystać tzw. terapię minutową, która polega na stosowaniu leku od początku w dużym stężeniu, ale przez znacznie krótszy czas (około 10-30 minut). Lek ma działanie redukujące, hamuje nadmierną proliferację keratynocytów. Istotną zaletą cygnoliny jest możliwość uzyskania u części chorych wielomiesięcznych remisji, wadą są jej złe właściwości kosmetyczne, gdyż może przebarwiać skórę i odzież, a także ma swoisty zapach, który nie zawsze jest akceptowany przez pacjentów. Ponadto cygnolina może powodować podrażnienia skóry i z tego powodu nie powinna być stosowana w okolice fałdów, na twarz (ryzyko podrażnień spojówek i przebarwień skóry) oraz $\mathrm{w}$ przypadku istnienia ostrozapalnych ognisk łuszczycy plackowatej.

Tazaroten jest obecnie jedynym miejscowym retinoidem dopuszczonym w Polsce do stosowania w leczeniu łuszczycy plackowatej, choć od dłuższego czasu nie jest dostępny w obrocie aptecznym. Tazaroten cechuje się mniejszym odsetkiem uzyskiwanej poprawy w porównaniu z innymi przeciwłuszczycowymi lekami do stosowania miejscowego, ale w chwili ustąpienia zmian łuszczycowych czas trwania remisji wydaje się dłuższy niż po zastosowaniu miejscowo glikokortykosteroidów lub pochodnych witaminy $\mathrm{D}_{3}$. Stosunkowo wysoka cena leku oraz możliwość wywoływania podrażnień skóry powoduje, że jest to rzadko stosowana forma leczenia, która może być zalecana w przypadku niepowodzenia terapii innymi lekami miejscowymi, niewielkich ognisk łuszczycy lub też jako terapia wspomagająca inne metody leczenia.

W terapii miejscowej łuszczycy stosowane są także dziegcie, najczęściej w stężeniach 5-10\%. Obecnie dostępny $\mathrm{w}$ formie leku recepturowego jest m.in. dziegieć sosnowy (Pix liquidi Pini). Ze względu na potencjalne działanie rakotwórcze, wykazane w badaniach in vitro i na zwierzętach, choć niepotwierdzone $\mathrm{u}$ ludzi, obecnie dziegcie stanowią formę terapii, rekomendowaną jedynie w wybranych przypadkach. W związku z potencjalnymi objawami niepożądanymi przepisy nie pozwalają na stosowanie dziegci z węgla kamiennego w kosmetykach. Dostępne są kosmetyki zawierające dziegieć brzozowy, bukowy, jałowcowy oraz sosnowy.

Inhibitory kalcyneuryny (pimekrolimus, takrolimus) są lekami zarejestrowanymi do leczenia atopo- 
ly regarded as one of the main therapeutic methods for more severe cases of plaque psoriasis. Provided that there are no contraindications to phototherapy, it should be considered in all patients with plaque psoriasis and moderate to severe psoriasis, and all other patients who have failed to achieve satisfactory control of the course of the disease by using topical treatment. Available phototherapy modalities in the treatment of psoriatic lesions include photochemotherapy with psoralens (PUVA), narrowband UVB $(311 \mathrm{~nm})$ phototherapy, and broadband UVB phototherapy. It is estimated that phototherapy may induce a $75 \%$ reduction in the Psoriasis Area and Severity Index (PASI) score in approximately 75\% (after UVB treatment) to $90 \%$ (after PUVA) of all patients with plaque psoriasis after approximately 4 to 6 weeks of therapy [6].

In patients with localised lesions, topical phototherapy may be applied (for example to the hands or feet only). The dose of radiation should be based on the minimal erythema dose (MED) for UVB or the minimal phototoxic dose (MPD) for PUVA determined prior to starting treatment. The dose can also be selected on the basis of the patient's skin phototype, but in such cases patients require closer monitoring in the initial period of therapy. During phototherapy, patients should receive regular dermatological follow-up examinations at least every 8 to 10 irradiation treatments. If a patient discontinues treatment temporarily, and the break period does not exceed one week, phototherapy can be resumed at the same dose as prior to the discontinuation. If phototherapy is interrupted for 2 weeks, the UV dose should be reduced by $25 \%$, and if the break period lasts 2-4 weeks, the dose should be reduced by half. In cases where phototherapy is interrupted for $>4$ weeks, the phototherapy regimen should be reintroduced starting with the lowest doses [7].

PUVA therapy usually involves oral administration of psoralens, but photosensitisers can also be applied topically - in the form of bath-PUVA (concentration of psoralens: $0.5-5.0 \mathrm{mg} / \mathrm{l}$ ), a solution or cream (concentration range: $0.005-1 \%$ ). The preferred frequency of irradiation treatments is 3 times a week (in justified cases, irradiation can be provided 2 or 4 times a week) [7]. Phototherapy or photochemotherapy combined with retinoids (acitretin) improves the efficacy of treatment and minimises the UV dose received by the patient.

During the irradiations, patients should use appropriate protection for the eyes and the anogenital area. Patients treated by PUVA need to be informed that after the administration of psoralens they will experience increased UV sensitivity for a few hours (approximately 7-8) [8]. While assessing patient eligibility for this treatment modality, the risk of photo- wego zapalenia skóry, mogą jednak stanowić cenne uzupełnienie miejscowej terapii łuszczycy, zwłaszcza w przypadku konieczności leczenia zmian chorobowych na twarzy oraz w okolicy anogenitalnej. Inhibitory kalcyneuryny zaleca się także w przypadkach łuszczycy odwróconej do stosowania w fałdach i zgięciach stawowych [5].

\section{FOTOTERAPIA I FOTOCHEMOTERAPIA}

Ze względu na dużą skuteczność oraz niewielką liczbę poważnych działań niepożądanych fototerapia stanowi obecnie jedną z podstawowych metod leczenia bardziej nasilonych przypadków łuszczycy plackowatej. Jeżeli nie ma przeciwwskazań do jej zastosowania, warto rozważyć wdrożenie fototerapii u pacjentów z łuszczycą plackowatą, umiarkowaną do ciężkiej oraz u pacjentów z łuszczycą o łagodnym nasileniu, jeśli nie uzyskano zadowalającej kontroli przebiegu choroby za pomocą leczenia miejscowego. Spośród dostępnych metod fototerapii w leczeniu zmian łuszczycowych można stosować fotochemoterapię z wykorzystaniem psolarenów (PUVA), fototerapię wąskim spektrum UVB $311 \mathrm{~nm}$ oraz szerokopasmowym UVB. Ocenia się, że fototerapia umożliwia uzyskanie redukcji wskaźnika PASI o 75\% (PASI75) u około 75\% (w przypadku naświetlań UVB) do nawet $90 \%$ (po zastosowaniu PUVA) wszystkich chorych na łuszczyce plackowatą po około 4-6 tygodniach leczenia, jak wskazuje metaanaliza Chen i wsp. [6]. Autorzy podkreślają jednak, że dotychczasowe dane są bardzo niejednorodne i należy je interpretować z ostrożnością [6].

W przypadku zmian zlokalizowanych można stosować fototerapię miejscową, naświetlając np. tylko ręce lub stopy. Dawkowanie promieniowania powinno być uzależnione od minimalnej dawki rumieniowej (minimal erythema dose - MED) dla UVB lub minimalnej dawki fototoksycznej (minimal phototoxic dose - MPD) dla PUVA, określonej przed rozpoczęciem leczenia. Możliwy jest także dobór dawki na podstawie fototypu skóry pacjenta, ale w takich przypadkach zaleca się ściślejsze monitorowanie chorego w początkowym okresie terapii. $W$ trakcie fototerapii kontrola dermatologiczna powinna być dokonywana nie rzadziej niż co 8-10 naświetlań. Przed każdym naświetlaniem wykwalifikowany pracownik ochrony zdrowia powinien ustalić ewentualne doraźne przeciwwskazania (np. cechy oparzenia). Jeżeli pacjent przerwał czasowo leczenie i okres przerwy nie przekracza tygodnia, może on powrócić do naświetlań w takiej samej dawce jak przed przerwą; jeśli przerwa w naświetlaniach wynosiła 2 tygodnie, to dawkę UV należy zmniejszyć o $25 \%$, przy przerwie 2-4-tygodniowej dawka rozpoczynająca ponowne naświetlania powinna zostać zredukowana o połowę, natomiast przy 
toxic or photoallergic reactions should be taken into account (table 1). The most important photosensitisers and/or phototoxic agents include tetracyclines, quinolines, phenothiazine derivatives, thiazide derivatives, loop diuretics, amiodarone, and griseofulvin.

\section{SYSTEMIC TREATMENT}

\section{Methotrexate}

Methotrexate (MTX) has recognised efficacy in the treatment of psoriasis. Advantages of the drug include low price, ease of use (once a week), relatively good tolerance and high efficacy in the therapy of psoriasis as well as psoriatic arthritis. MTX can be administered orally or subcutaneously. The drug dose with immunomodulatory activity is in the range of 5 to $30 \mathrm{mg} /$ week, and the recommended dose in most patients is in the range of 15 to $20 \mathrm{mg} /$ week. Treatment can be started with low doses (5-7.5 mg/week), especially in patients who are treated with MTX for the first time, with a follow-up evaluation prior to the administration of the next drug dose. Afterwards the dose may be increased to $15 \mathrm{mg}$ / week. If the resolution of skin lesions is insufficient during 8 weeks of treatment, an increase in drug dose to $20 \mathrm{mg}$ / week (maximum $25 \mathrm{mg}$ / week in przerwie powyżej 4 tygodni konieczne jest rozpoczęcie cyklu fototerapii od najmniejszych dawek [7].

W przypadku PUVA najczęściej podaje się psoraleny doustnie, jednak możliwa jest również aplikacja miejscowa fotouczulaczy, zarówno w postaci kąpieli (tzw. bath-PUVA, stosowane stężenia psoralenów: 0,5-5,0 mg/1), jak i roztworu lub kremu (stosowane stężenia: 0,005-1\%). Preferowana częstość naświetlań to 3 razy w tygodniu (w uzasadnionych przypadkach naświetlania można prowadzić 2 lub 4 razy na tydzień) [7]. Połączenie fototerapii lub fotochemoterapii z retinoidami (acytretyną) poprawia skuteczność leczenia i pozwala na zminimalizowanie dawki UV otrzymanej przez pacjenta.

W czasie naświetlań pacjenci powinni stosować właściwą protekcję oczu i okolicy anogenitalnej. W przypadku PUVA chorzy muszą być poinformowani, że przez kilka godzin od zażycia psoralenów (około 7-8 godzin) mają zwiększoną wrażliwość na UV [8]. W trakcie kwalifikowania należy uwzględnić możliwość wystąpienia odczynów fototoksycznych lub fotoalergicznych (tab. 1). Do najważniejszych leków fotouczulających i/lub fototoksycznych należą: tetracykliny, chinolony, pochodne fenotiazyny,

Table I. Adverse reactions and contraindications to phototherapy and photochemotherapy

\begin{tabular}{|c|c|c|}
\hline Parameter & PUVA & UVB \\
\hline Early complications & $\begin{array}{l}\text { Erythema and burning sensation (common) } \\
\text { Pruritus due to xerosis } \\
\text { Bullous reactions } \\
\text { Induction of photodermatoses } \\
\text { Skin infections (HSV) } \\
\text { Nausea and vomiting (associated with psoralens) } \\
\text { Hepatotoxicity (uncommon, associated with } \\
\text { psoralens) } \\
\text { Transient maculopapular rash }\end{array}$ & $\begin{array}{l}\text { Erythema and burning sensation (common) } \\
\text { Pruritus due to xerosis } \\
\text { Bullous reactions } \\
\text { Induction of photodermatoses } \\
\text { Skin infections (HSV) }\end{array}$ \\
\hline Late complications & $\begin{array}{l}\text { Induction of skin carcinogenesis } \\
\text { Accelerated skin photoaging } \\
\text { Ocular damage } \\
\text { PUVA-keratoses } \\
\text { PUVA-lentigines }\end{array}$ & $\begin{array}{l}\text { Induction of skin carcinogenesis } \\
\text { Accelerated skin photoaging } \\
\text { Ocular damage }\end{array}$ \\
\hline Absolute contraindications & $\begin{array}{l}\text { Photodermatoses/photosensitivity } \\
\text { Skin malignancies } \\
\text { Pregnancy and lactation }\end{array}$ & $\begin{array}{l}\text { Photodermatoses/photosensitivity } \\
\text { Skin malignancies }\end{array}$ \\
\hline Relative contraindications & $\begin{array}{l}\text { Use of drugs with photosensitising and/or } \\
\text { phototoxic effects } \\
\text { Cyclosporin A therapy } \\
\text { Atypical mole syndrome } \\
\text { History of skin malignancies } \\
\text { Active skin infections } \\
\text { Claustrophobia (closed cabins) } \\
\text { Heart failure (NYHA III-IV) } \\
\text { Epilepsy } \\
\text { Eye diseases (including cataract, keratitis, } \\
\text { maculopathy) } \\
\text { Age }<\text { I } 2 \text { years } \\
\text { Pronounced liver damage } \\
\text { Cumulative dose of PUVA }>2000 \text { J/cm² }\end{array}$ & $\begin{array}{l}\text { Use of drugs with photosensitising and/or } \\
\text { phototoxic effects } \\
\text { Cyclosporin A therapy } \\
\text { Atypical mole syndrome } \\
\text { History of skin malignancies } \\
\text { Active skin infections } \\
\text { Claustrophobia (closed cabins) } \\
\text { Heart failure (NYHA III-IV) } \\
\text { Epilepsy } \\
\text { Eye diseases (including cataract, keratitis, } \\
\text { maculopathy) }\end{array}$ \\
\hline
\end{tabular}


Tabela I. Działania niepożądane i przeciwwskazania do fototerapii i fotochemoterapii

\begin{tabular}{|c|c|c|}
\hline Parametr & PUVA & UVB \\
\hline Powikłania wczesne & $\begin{array}{l}\text { Rumień i pieczenie (często) } \\
\text { Świąd spowodowany nadmierną suchością skóry } \\
\text { Odczyny pęcherzowe } \\
\text { Prowokacja fotodermatoz } \\
\text { Infekcje skórne (HSV) } \\
\text { Nudności i wymioty (związane z przyjmowaniem } \\
\text { psoralenów) } \\
\text { Hepatotoksyczność (rzadko - związana } \\
\text { z przyjmowaniem psoralenów) } \\
\text { Przemijająca osutka plamisto-grudkowa }\end{array}$ & $\begin{array}{l}\text { Rumień i pieczenie (często) } \\
\text { Świąd spowodowany nadmierną suchością skóry } \\
\text { Odczyny pęcherzowe } \\
\text { Prowokacja fotodermatoz } \\
\text { Infekcje skórne (HSV) }\end{array}$ \\
\hline Powikłania późne & $\begin{array}{l}\text { Indukowanie kancerogenezy skórnej } \\
\text { Przyspieszone fotostarzenie skóry } \\
\text { Uszkodzenie narządu wzroku } \\
\text { Rogowacenie indukowane PUVA (tzw. PUVA- } \\
\text {-keratoses) } \\
\text { Tzw. PUVA-lentigines }\end{array}$ & $\begin{array}{l}\text { Indukowanie kancerogenezy skórnej } \\
\text { Przyspieszone fotostarzenie skóry } \\
\text { Uszkodzenie narządu wzroku }\end{array}$ \\
\hline $\begin{array}{l}\text { Przeciwwskazania } \\
\text { bezwzględne }\end{array}$ & $\begin{array}{l}\text { Fotodermatozy lub fotonadwrażliwość } \\
\text { Nowotwory złośliwe skóry } \\
\text { Ciąża i laktacja }\end{array}$ & $\begin{array}{l}\text { Fotodermatozy lub fotonadwrażliwość } \\
\text { Nowotwory złośliwe skóry }\end{array}$ \\
\hline Przeciwwskazania względne & $\begin{array}{l}\text { Stosowanie leków fotouczulających i/lub } \\
\text { fototoksycznych } \\
\text { Terapia cyklosporyną A } \\
\text { Zespół znamion atypowych } \\
\text { Nowotwory złośliwe skóry w przeszłości } \\
\text { Czynne infekcje skórne } \\
\text { Klaustrofobia (zamykane kabiny) } \\
\text { Niewydolność krążenia NYHA III-IV } \\
\text { Padaczka } \\
\text { Choroby narządu wzroku (m.in. zaćma, } \\
\text { zapalenie rogówki, zwyrodnienie plamki) } \\
\text { Wiek < I } 2 \text { lat } \\
\text { Uszkodzenie wątroby znacznego stopnia } \\
\text { Otrzymanie dawki kumulacyjnej PUVA } \\
>2000 \mathrm{~J} / \mathrm{cm}^{2}\end{array}$ & $\begin{array}{l}\text { Stosowanie leków fotouczulających i/lub } \\
\text { fototoksycznych } \\
\text { Terapia cyklosporyną A } \\
\text { Zespół znamion atypowych } \\
\text { Nowotwory złośliwe skóry w przeszłości } \\
\text { Czynne infekcje skórne } \\
\text { Klaustrofobia (zamykane kabiny) } \\
\text { Niewydolność krążenia NYHA III-IV } \\
\text { Padaczka } \\
\text { Choroby narządu wzroku (m.in. zaćma, } \\
\text { zapalenie rogówki, zwyrodnienie plamki) }\end{array}$ \\
\hline
\end{tabular}

some cases) is indicated. It is estimated that a satisfactory therapeutic response is observed in approximately $50-60 \%$ of patients with psoriasis vulgaris $[9,10]$. A significant improvement is usually noted after 7-13 weeks of therapy, with higher starting doses leading to faster improvement. The maximum efficacy of MTX is typically achieved after 12-20 weeks of treatment.

Subcutaneous administration of MTX results in high bioavailability and limited gastrointestinal adverse reactions, and it is convenient for patients (table 2). Subcutaneously administered MTX shows slightly higher efficacy compared to the same dose of the drug taken via the oral route, with comparable safety profiles.

Methotrexate can be used for as long as it is effective and well tolerated by the patient. The drug must not be used during pregnancy, and patients treated with MTX (both women and men) should not plan to conceive a child for the entire duration of therapy and at least 3 months after its completion (based on medical literature reports). Importantly, patient information leaflets prepared by manufacturers of MTX-containing drugs recommend effective contraception for 6 months after the end of treatment. Other pochodne tiazydowe, diuretyki pętlowe, amiodaron oraz gryzeofulwina.

\section{LECZENIE OGÓLNE}

\section{Metotreksat}

Metotreksat (MTX) jest lekiem o uznanym działaniu przeciwłuszczycowym. Do jego zalet należą niska cena, łatwość stosowania (raz w tygodniu), stosunkowo dobra tolerancja i skuteczność w łuszczycy oraz łuszczycowym zapaleniu stawów (łuszczycy stawowej). Metotreksat może być podawany podskórnie lub doustnie. Dawka leku o działaniu immunomodulującym mieści się w granicach 5-30 mg/tydzien, dla większości pacjentów rekomendowana jest dawka 15-20 mg/tydzień. Leczenie można rozpoczynać od niskich dawek (57,5 mg/tydzień), zwłaszcza u pacjentów leczonych MTX po raz pierwszy, z następczą kontrolą przed podaniem kolejnej dawki leku. Dawkowanie można następnie zwiększyć do $15 \mathrm{mg}$ /tydzień. W przypadku niewystarczającej poprawy zmian skórnych w czasie 8 tygodni leczenia wskazane jest zwiększenie dawki leku do 20 mg/ 
Table 2. Recommendations on the use of methotrexate in psoriasis

\begin{tabular}{|c|c|c|}
\hline \multicolumn{2}{|c|}{ Recommended dose } & $\begin{array}{l}\text { I0-20 mg/week, maximum dose: } 25 \text { mg/week (maintenance dose: } 7.5 \text {-20 mg/ } \\
\text { week) } \\
\text { Folic acid at doses of } 10-15 \mathrm{mg} / \text { week is recommended during therapy }\end{array}$ \\
\hline \multicolumn{2}{|c|}{ Recommended treatment period } & $\begin{array}{l}\text { Long-term therapy in adults (provided that the drug is effective and causes no } \\
\text { significant adverse reactions) } \\
\text { Until disease control is achieved in children }\end{array}$ \\
\hline \multirow[t]{2}{*}{$\begin{array}{l}\text { Recommended } \\
\text { laboratory tests }\end{array}$} & $\begin{array}{l}\text { Before starting } \\
\text { treatment }\end{array}$ & $\begin{array}{l}\text { Activity of liver enzymes in serum } \\
\text { Total bilirubin concentration in serum } \\
\text { CBC with differential } \\
\text { Serum creatinine concentration } \\
\text { C-reactive protein (CRP) or erythrocyte sedimentation rate (ESR) } \\
\text { Viral hepatitis tests (HBs antigen, anti-HCV) } \\
\text { Pregnancy test (urine or serum) in women of reproductive age } \\
\text { Optionally: } \\
\text { Total protein and albumin concentration in serum } \\
\text { Lung X-ray } \\
\text { Abdominal ultrasound } \\
\text { HIV test }\end{array}$ \\
\hline & Every I-3 months & $\begin{array}{l}\text { Activity of liver enzymes in serum } \\
\text { CBC with differential } \\
\text { Serum creatinine concentration }\end{array}$ \\
\hline \multicolumn{2}{|c|}{ Major adverse reactions } & $\begin{array}{l}\text { Liver damage, cirrhosis } \\
\text { Stomatitis, ulcers in the oral cavity } \\
\text { Gastrointestinal disorders, diarrhoea } \\
\text { Loss of appetite } \\
\text { Feeling of fatigue } \\
\text { Pneumonia, alveolitis } \\
\text { Myelosuppression: leukopaenia, thrombocytopaenia, anaemia } \\
\text { Miscarriages, infertility } \\
\text { Alopecia }\end{array}$ \\
\hline \multicolumn{2}{|c|}{ Absolute contraindications } & $\begin{array}{l}\text { Severe infections } \\
\text { Severe liver and/or kidney damage } \\
\text { Active hepatitis B and C } \\
\text { Bone marrow diseases } \\
\text { Immunodeficiencies } \\
\text { Significant leukopaenia, thrombocytopaenia, anaemia } \\
\text { Pulmonary fibrosis } \\
\text { Alcohol or drug abuse } \\
\text { Active peptic ulcer disease } \\
\text { Pregnancy and pregnancy planning } \\
\text { Breast-feeding }\end{array}$ \\
\hline \multicolumn{2}{|c|}{ Relative contraindications } & $\begin{array}{l}\text { Mild to moderate liver injury } \\
\text { Latent hepatitis B and C } \\
\text { Moderate kidney injury } \\
\text { Ulcerative colitis } \\
\text { Gastritis } \\
\text { Diabetes } \\
\text { History of neoplastic diseases (up to } 5 \text { years) } \\
\text { Circulatory failure } \\
\text { Treatment with of other hepatotoxic and myelotoxic drugs }\end{array}$ \\
\hline
\end{tabular}

adverse reactions are listed in table 2 . In the majority of cases, the risk of liver damage is low, provided that MTX is not used by patients with concomitant liver diseases (hepatitis B, hepatitis C), abusing alcohol, with obesity, diabetes or receiving concurrent therapy with other hepatotoxic drugs. To lower the risk of some adverse reactions, patients treated with MTX are advised to take folic acid prophylactically (e.g. $10 \mathrm{mg} /$ week of folic acid for MTX doses $\leq 15 \mathrm{mg} /$ week, $15 \mathrm{mg} /$ week of folic acid for MTX doses higher tydzień (do maksymalnie $25 \mathrm{mg} /$ tydzień w niektórych przypadkach). Ocenia się, że zadowalający efekt terapeutyczny uzyskuje się u około 50-60\% chorych na łuszczycę zwykłą $[9,10]$. Istotna poprawa następuje zazwyczaj po 7-13 tygodniach terapii, przy czym wyższe dawki początkowe prowadzą do szybszej poprawy. Maksymalna skuteczność MTX osiągana jest najczęściej po 12-20 tygodniach leczenia.

Podskórna droga podania MTX zapewnia wysoką biodostępność, pozwala na ograniczenie działań 
Tabela 2. Zasady stosowania metotreksatu w leczeniu łuszczycy

\begin{tabular}{|c|c|c|}
\hline \multicolumn{2}{|c|}{ Rekomendowana dawka } & $\begin{array}{l}\text { I0-20 mg/tydzień, maksymalnie } 25 \text { mg/tydzień (dawka podtrzymująca 7,5-20 mg/ } \\
\text { tydzień) } \\
\text { W czasie terapii zaleca się stosowanie I0-15 mg/tydzień kwasu foliowego }\end{array}$ \\
\hline \multicolumn{2}{|c|}{ Rekomendowany okres terapii } & $\begin{array}{l}\text { Długotrwale u dorosłych (jeśli lek jest skuteczny i nie stwierdza się istotnych działań } \\
\text { niepożądanych) } \\
\text { Do czasu uzyskania kontroli choroby u dzieci }\end{array}$ \\
\hline \multirow[t]{2}{*}{$\begin{array}{l}\text { Zalecane badania } \\
\text { laboratoryjne }\end{array}$} & Przed leczeniem & $\begin{array}{l}\text { Aktywność enzymów wątrobowych w surowicy } \\
\text { Całkowite stężenie bilirubiny w surowicy } \\
\text { Morfologia krwi z rozmazem } \\
\text { Stężenie kreatyniny w surowicy } \\
\text { Białko C-reaktywne (CRP) lub odczyn Biernackiego (OB) } \\
\text { Badania wirusologiczne wątroby (antygen HBs, anty-HCV) } \\
\text { Test ciążowy (mocz lub surowica) u kobiet w okresie rozrodczym } \\
\text { Opcjonalnie: } \\
\text { Całkowite stężenie białka i albumin w surowicy } \\
\text { RTG płuc } \\
\text { USG jamy brzusznej } \\
\text { HIV }\end{array}$ \\
\hline & Co I-3 miesiące & $\begin{array}{l}\text { Aktywność enzymów wątrobowych w surowicy } \\
\text { Morfologia krwi z rozmazem } \\
\text { Stężenie kreatyniny w surowicy }\end{array}$ \\
\hline \multicolumn{2}{|c|}{ Najważniejsze działania niepożądane } & $\begin{array}{l}\text { Uszkodzenie wątroby, marskość wątroby } \\
\text { Zapalenie i owrzodzenia błony śluzowej jamy ustnej (stomatitis) } \\
\text { Dolegliwości żołądkowo-jelitowe, biegunka } \\
\text { Utrata apetytu } \\
\text { Uczucie zmęczenia } \\
\text { Zapalenie płuc, alveolitis } \\
\text { Mielosupresja: leukopenia, trombocytopenia, niedokrwistość } \\
\text { Poronienia, bezpłodność } \\
\text { Łysienie }\end{array}$ \\
\hline \multicolumn{2}{|c|}{ Przeciwwskazania bezwzględne } & $\begin{array}{l}\text { Poważne zakażenia } \\
\text { Ciężkie uszkodzenie wątroby i/lub nerek } \\
\text { Aktywne wirusowe zapalenie wątroby typu B i C } \\
\text { Choroby szpiku kostnego } \\
\text { Niedobory odporności } \\
\text { Istotna leukopenia, trombocytopenia, niedokrwistość } \\
\text { Zwłóknienie płuc } \\
\text { Nadużywanie alkoholu lub narkotyków } \\
\text { Czynna choroba wrzodowa żołądka } \\
\text { Ciąża i planowanie ciąży } \\
\text { Karmienie piersią }\end{array}$ \\
\hline \multicolumn{2}{|c|}{ Przeciwwskazania względne } & $\begin{array}{l}\text { Lekkie do umiarkowanego uszkodzenie wątroby } \\
\text { Latentne wirusowe zapalenie wątroby typu B i C } \\
\text { Umiarkowane uszkodzenie nerek } \\
\text { Wrzodziejące zapalenie jelita grubego } \\
\text { Zapalenie błony śluzowej żołądka } \\
\text { Cukrzyca } \\
\text { Choroby nowotworowe w wywiadzie (do } 5 \text { lat) } \\
\text { Niewydolność układu krążenia } \\
\text { Stosowanie innych leków hepato- i mielotoksycznych }\end{array}$ \\
\hline
\end{tabular}

than $15 \mathrm{mg} /$ week) [11]. MTX treatment can be provided in the form of subcutaneous or intramuscular injections in patients who are unable to tolerate MTX administered orally (as manifested by nausea and/ or vomiting). Treatment can also be initiated via the parenteral route and continued in this form or - depending on medical indications or patient preferences - switched to the oral route.

Follow-up examinations with evaluation of the severity of psoriatic lesions should be conduct- niepożądanych ze strony przewodu pokarmowego i jest wygodna dla pacjentów (tab. 2). W formie podskórnej MTX wykazuje nieco wyższą skuteczność od tej samej dawki leku podanej w formie doustnej, przy porównywalnym profilu bezpieczeństwa.

Metotreksat może być stosowany tak długo, jak długo jest skuteczny i dobrze tolerowany przez pacjenta. Leku nie należy stosować w ciąży, a osoby przyjmujące MTX (kobiety i mężczyźni) nie mogą planować poczęcia dziecka przez cały czas terapii i przynajmniej przez 
ed approximately every 4 weeks during the initial 3 months of therapy, and at a lower frequency (e.g. every 8-12 weeks) afterwards. Also, a complete blood count should be performed in patients treated with MTX for the first time approximately 7-14 days after taking the first dose, and later at a frequency of about every 4 weeks together with the evaluation of creatinine concentration and liver enzyme activity in the serum. In order to monitor the risk of liver fibrosis in patients during chronic Mtx treatment, one of the following examinations may be considered: evaluation of N-terminal propeptide of type III procollagen (P3NP), enhanced liver fibrosis (ELF) test based on the quantitative measurement of three hepatic markers: hyaluronic acid, amino-terminal propeptide of type III procollagen, and extracellular matrix metalloproteinase-1 inhibitor, FibroTest ${ }^{\circledR}$ or dynamic elastography $\left(\right.$ FibroScan $\left.^{\circledR}\right)$. Routine liver biopsy is not currently recommended in patients undergoing MTX therapy, though it may be considered in specific cases. In the event of MTX overdose the drug should be discontinued, and the patient should be hospitalised and receive intravenous injections of folinic acid until complete elimination of MTX from the body.

\section{Cyclosporin A}

Cyclosporin A (CsA) is a small cyclic polypeptide with a molecular weight of $1200 \mathrm{kDa}$. Because of its large molecular weight, the drug does not penetrate through the skin, and should not be used topically (with the exception of topical application of CsA into the conjunctival sac). CsA molecule does not have a charge, and it is soluble in organic solvents and fats, but insoluble in water. Fat-rich food products contribute to an improved absorption of CsA.

The therapeutic oral dose of the drug is within the range of 2.5 to $5 \mathrm{mg} / \mathrm{kg} \mathrm{bw} /$ day. If the drug is administered intravenously, the dose should be reduced at a ratio of $1: 3$ in relation to the due oral dose. CsA does not cross the blood-brain barrier, and it passes slightly through the placental barrier. The drug may potentially be used in pregnant women, but in each case it should be considered whether the benefits of CsA treatment outweigh potential adverse reactions. CsA does not show teratogenic effects, but it may increase the risk of premature labour. It should also be noted that CsA capsules contain ethanol. Since CsA is soluble in fats, it may be excreted into the milk of breast-feeding women. Consequently, the drug should not be used during breast-feeding. If the mother receives treatment with CsA during lactation, she should be advised to switch to formula feeding.

According to the European recommendations CsA is currently indicated primarily for short-term treatment of psoriasis aimed at achieving rapid improvement. Therapy longer than 3-6 months is not usually
3 miesiące po jej zakończeniu (według danych literaturowych). Należy pamiętać, że producenci preparatów MTX rekomendują w ulotkach stosowanie skutecznej antykoncepcji przez 6 miesięcy po zakończeniu leczenia. Objawy niepożądane przedstawiono w tabeli 2 . W większości przypadków ryzyko uszkodzenia wątroby jest niskie, pod warunkiem że lek nie jest stosowany u osób $\mathrm{z}$ innymi chorobami wątroby (wirusowe zapalenie wątroby typu B i C), nadużywających alkoholu, otyłych, z cukrzycą oraz stosujących inne leki hepatotoksyczne. Zaleca się, aby osoby zażywające MTX stosowały profilaktycznie kwas foliowy (np. $10 \mathrm{mg} /$ tydzień kwasu foliowego dla dawek MTX $\leq 15 \mathrm{mg} /$ tydzień; $15 \mathrm{mg} /$ tydzień kwasu foliowego, jeśli dawka MTX jest wyższa niż $15 \mathrm{mg}$ /tydzień), gdyż pozwala to ograniczyć ryzyko wystąpienia niektórych działań niepożądanych [11]. Jeśli po podaniu doustnym MTX stwierdza się nietolerancję leku (występowanie nudności i/lub wymiotów), leczenie można prowadzić w postaci iniekcji podskórnych lub domięśniowych. Można również rozpocząć leczenie od stosowania formy pozajelitowej i tak kontynuować lub zmienić na formę doustną, jeśli jest to uzasadnione medycznie albo preferencjami pacjenta.

Badanie lekarskie $\mathrm{z}$ oceną nasilenia zmian łuszczycowych rekomendowane jest co około 4 tygodnie $\mathrm{w}$ pierwszych 3 miesiącach i następnie $\mathrm{z}$ mniejszą częstością (np. co 8-12 tygodni). W przypadku pierwszorazowego zastosowania MTX kontrola morfologii krwi powinna być wykonana około 7-14 dni po przyjęciu pierwszej dawki, a następnie co około 4 tygodnie wraz z oznaczeniem stężenia kreatyniny oraz aktywności enzymów wątrobowych w surowicy. W celu monitorowania ewentualnego procesu włóknienia wątroby w trakcie przewlekłego leczenia MTX można rozważyć wykonanie któregokolwiek badania spośród następujących: ocena stężenia N-końcowego peptydu prokolagenu typu III (P3NP) lub test ELF (Enhanced Liver Fibrosis) oparty na pomiarze ilościowym trzech markerów wątrobowych: kwasu hialuronowego, aminokońcowego propeptydu prokolagenu typu III i inhibitora metaloproteinazy 1 macierzy pozakomórkowej, FibroTest ${ }^{\circledR}$ lub badanie elastografii dynamicznej $\left(\right.$ FibroScan $\left.^{\circledR}\right)$. Obecnie nie zaleca się rutynowego badania wycinka wątroby w trakcie terapii MTX, choć w szczególnych przypadkach taka biopsja może być rozważona. W razie przedawkowania MTX lek należy odstawić, a pacjent powinien być hospitalizowany i otrzymywać dożylnie kwas folinowy do czasu pełnego wyeliminowania MTX z organizmu.

\section{Cyklosporyna A}

Cyklosporyna A (CyA) to mały cykliczny polipeptyd o masie $1200 \mathrm{kDa}$. Ze względu na dużą masę cząsteczkową nie przenika przez skórę i nie powinien być stosowany miejscowo (z wyjątkiem CyA aplikowanej do worka spojówkowego). Cząsteczka 
indicated (table 3). If necessary, CsA treatment may be continued in patients with a good clinical response for a period of up to 2 years or even longer. Longer CsA therapy (> 2 years) should be carefully monitored because of an increased risk of adverse drug reactions including skin cancer, especially in patients with a history of PUVA treatment [12]. A significant clinical improvement is observed after approximately 4-6 weeks of CsA therapy, and maximum efficacy is achieved after approximately $5-12$ weeks of treatment. Higher doses of CsA (5 mg/ kg bw/day) lead to a more rapid clinical improvement that can be observed already after 3-4 weeks. Approximately 30\% of patients achieve PASI-90 score [9].

All patients treated with CsA need to be monitored according to applicable guidelines (table 3). Also, patients should perform daily arterial blood pressure measurements. If the treatment is well tolerated, and the dose of the drug has not been modified, the frequency of arterial blood pressure measurements may be reduced. Dermoscopy is recommended once a year in order to rule out precancerous conditions and skin cancers.

There is no need to evaluate the serum concentration of CsA on an outpatient basis. However, determining the concentration of the drug may be beneficial in patients treated for psoriasis who fail to achieve a satisfactory response to therapy. CsA-related adverse reactions in the kidneys are dose-dependent and occur almost exclusively in patients with prolonged exposure to CsA or taking doses in excess of $5 \mathrm{mg} / \mathrm{kg}$ bw/day. The most significant adverse reactions triggered by CsA include kidney injury, arterial hypertension, infections and malignant cancers (table 3) [13].

If the estimated glomerular filtration rate (eGFR) level is found to have decreased by $\geq 25 \%$ relative to the baseline in more that one assay during therapy, the dose of CsA should be reduced by $25-50 \%$. However, if normalisation of kidney function parameters is still not achieved within 2 to 4 weeks after dose reduction, the drug should be discontinued. In their early stage, kidney disorders are typically functional in nature, and they resolve completely after the dose of CsA is reduced or the drug is discontinued. History of an increased creatinine concentration during CsA treatment is not an absolute contraindication to undertaking another therapeutic attempt if the creatinine concentration is within the normal range. The risk of developing cyclosporin-induced nephropathy is elevated if the patient has coexisting uncontrolled arterial hypertension or other kidney conditions, receives concomitant treatment with other drugs inducing nephrotoxic effects (especially NSAIDs), and in the elderly population. Supplementation with magnesium may help mitigate the nephrotoxic potential of CsA.
CyA nie ma ładunku i rozpuszcza się w rozpuszczalnikach organicznych i tłuszczach, nie jest natomiast rozpuszczalna w wodzie. Pokarmy bogate w tłuszcze przyczyniają się do lepszego wchłaniania CyA.

Dawka terapeutyczna leku w postaci doustnej mieści się w granicach 2,5-5 mg/kg m.c./dobę. W przypadku podawania leku dożylnie dawka powinna być zmniejszona w proporcji $1: 3 \mathrm{w}$ stosunku do należnej dawki doustnej. CyA nie przechodzi przez barierę krew-mózg, słabo także przenika przez barierę łożyskową. CyA może być potencjalnie stosowana u kobiet $\mathrm{w}$ ciąży, choć zawsze należy rozważyć, czy korzyść z zastosowania CyA przeważa nad ewentualnym ryzykiem wystąpienia działań niepożądanych. CyA nie ma działania teratogennego, może jednak zwiększać ryzyko porodu przedwczesnego. Trzeba także pamiętać, że kapsułki CyA zawierają etanol. Z uwagi na rozpuszczanie się CyA w tłuszczach lek ten przenika do mleka matek karmiących, dlatego CyA nie powinna być stosowana w okresie karmienia piersią, a jeżeli matka w okresie laktacji przyjmuje CyA, to należy zalecić karmienie sztuczne.

Zgodnie z rekomendacjami europejskimi w łuszczycy CyA jest obecnie zalecana głównie w sytuacjach, kiedy przewidziane jest krótkotrwałe leczenie, które ma na celu szybkie uzyskanie poprawy. Zazwyczaj nie rekomenduje się terapii trwającej dłużej niż 3-6 miesięcy (tab. 3). W razie konieczności terapia CyA może być kontynuowana u pacjentów z dobrą odpowiedzią kliniczną do 2 lat lub dłużej. Dłuższe leczenie CyA (> 2 lata) należy prowadzić z ostrożnością ze względu na zwiększone ryzyko wystąpienia objawów niepożądanych, w tym rozwoju raków skóry, zwłaszcza u pacjentów leczonych w przeszłości PUVA [12]. Istotną poprawę kliniczną obserwuje się po około 4-6 tygodniach terapii CyA, natomiast maksymalna skuteczność uzyskiwana jest po około 5-12 tygodniach leczenia. Zastosowanie większych dawek CyA (5 mg/kg m.c./dobę) pozwala na uzyskanie szybszej poprawy klinicznej, już po 3-4 tygodniach. Około 30\% pacjentów uzyskuje poprawę PASI-90 [9].

Wszyscy pacjenci w trakcie terapii CyA powinni być monitorowani zgodnie z zaleceniami (tab. 3). Pacjent powinien codziennie samodzielnie dokonywać pomiaru ciśnienia tętniczego krwi. W przypadku dobrej tolerancji leczenia i jeśli dawka nie była zmieniana, częstość pomiaru ciśnienia może być zmniejszona. Raz do roku rekomendowane jest badanie dermoskopowe w celu wykluczenia stanów przedrakowych i raków skóry.

W warunkach ambulatoryjnych nie ma potrzeby oznaczania stężenia CyA w surowicy. Oznaczenie stężenia leku u pacjentów leczonych z powodu łuszczycy może być wskazane w przypadkach braku zadowalającej odpowiedzi na leczenie. Działania niepożądane ze strony nerek związane z zastosowaniem CyA są za- 
Table 3. Recommendations on the use of cyclosporin A in psoriasis

\begin{tabular}{|c|c|c|}
\hline Recommended c & & $2.5-5 \mathrm{mg} / \mathrm{kg}$ bw/day p.o. \\
\hline Recommended c & n of treatment & 3-6 months (maximum: 2 years) \\
\hline $\begin{array}{l}\text { Recommended } \\
\text { laboratory tests }\end{array}$ & $\begin{array}{l}\text { Before starting } \\
\text { treatment }\end{array}$ & $\begin{array}{l}\text { Creatinine concentration (twice) } \\
\text { Glomerular filtration rate (GFR) } \\
\text { CBC with differential } \\
\text { Aminotransferases (AST, ALT) } \\
\text { Electrolytes (sodium, potassium, magnesium) } \\
\text { C-reactive protein (CRP) or erythrocyte sedimentation rate (ESR) } \\
\text { Serum glucose concentration } \\
\text { General urine analysis } \\
\text { Optionally: } \\
\text { Lipid panel (triglycerides and cholesterol) } \\
\text { Viral hepatitis tests, HIV } \\
\text { Lung X-ray } \\
\text { Pregnancy test }\end{array}$ \\
\hline & $\begin{array}{l}\text { Approximately } \\
\text { every I-3 months }\end{array}$ & $\begin{array}{l}\text { Serum creatinine concentration (with calculation of GFR) } \\
\text { CBC with differential } \\
\text { Aminotransferases (AST, ALT) } \\
\text { Electrolytes (sodium, potassium, magnesium) } \\
\text { General urine analysis } \\
\text { Optionally: } \\
\text { Lipid panel (triglycerides and cholesterol) } \\
\text { Serum glucose concentration }\end{array}$ \\
\hline & $\begin{array}{l}\text { Approximately } \\
\text { every } 12 \text { months }\end{array}$ & $\begin{array}{l}\text { Optionally: } \\
\text { Lung X-ray }\end{array}$ \\
\hline Major adverse re & & $\begin{array}{l}\text { Kidney dysfunction } \\
\text { Arterial hypertension } \\
\text { Development of skin cancers } \\
\text { Gingival hyperplasia } \\
\text { Hypertrichosis } \\
\text { Tremor (uncommonly: convulsions) } \\
\text { Feeling of fatigue } \\
\text { Hyperlipidaemia } \\
\text { Myopathy (if CsA is used in combination with statins) } \\
\text { Gastrointestinal ulcers } \\
\text { Hyperglycaemia } \\
\text { Hyperuricaemia } \\
\text { Hyperkalaemia } \\
\text { Hypomagnesaemia }\end{array}$ \\
\hline Absolute contrai & ions & $\begin{array}{l}\text { Hypersensitivity to CsA } \\
\text { Severe liver injury } \\
\text { Severe infections } \\
\text { Severe uncontrolled arterial hypertension } \\
\text { Malignant cancer } \\
\text { Concurrent PUVA therapy }\end{array}$ \\
\hline Relative contrain & ons & $\begin{array}{l}\text { Gout } \\
\text { Kidney dysfunction } \\
\text { Liver diseases } \\
\text { Hyperkalaemia } \\
\text { Cumulative dose of PUVA > } 2000 \mathrm{~J} / \mathrm{cm}^{2} \\
\text { Concurrent UVB phototherapy } \\
\text { Concurrent treatment with other nephrotoxic drugs } \\
\text { Concurrent treatment with acitretin } \\
\text { Breast-feeding }\end{array}$ \\
\hline
\end{tabular}

CsA should not be used in conjunction with PUVA or other phototherapeutic modalities, as the combination markedly elevates the risk of developing skin cancer. Also, caution should be exercised when prescribing CsA to patients with a history of multiple PUVA treatments, especially when the cumulative leżne od dawki i występują niemal wyłącznie podczas przedłużonej ekspozycji na CyA lub przy dawkach przekraczających $5 \mathrm{mg} / \mathrm{kg}$ m.c./dobę. Do najważniejszych objawów niepożądanych związanych za stosowaniem CyA należą: uszkodzenie nerek, nadciśnienie tętnicze, infekcje i nowotwory złośliwe (tab. 3) [13]. 
Tabela 3. Zasady stosowania cyklosporyny A w leczeniu łuszczycy

\begin{tabular}{|c|c|c|}
\hline Rekomendowana & & 2,5-5 mg/kg m.c./dobę p.o. \\
\hline Rekomendowany & leczenia & 3-6 miesięcy (maks. do 2 lat) \\
\hline $\begin{array}{l}\text { Zalecane badania } \\
\text { laboratoryjne }\end{array}$ & Przed leczeniem & $\begin{array}{l}\text { Stężenie kreatyniny (dwukrotnie) } \\
\text { Przesączanie kłębuszkowe (GFR) } \\
\text { Morfologia krwi z rozmazem } \\
\text { Aminotransferazy (AspAT, AIAT) } \\
\text { Elektrolity (sód, potas, magnez) } \\
\text { Białko C-reaktywne (CRP) lub odczyn Biernackiego (OB) } \\
\text { Stężenie glukozy w surowicy } \\
\text { Badanie ogólne moczu } \\
\text { Opcjonalnie: } \\
\text { Lipidogram (cholesterol i trójglicerydy) } \\
\text { Badania wirusologiczne wątroby, HIV } \\
\text { RTG płuc } \\
\text { Próba ciążowa }\end{array}$ \\
\hline & $\begin{array}{l}\text { Co ok. I-3 } \\
\text { miesiące }\end{array}$ & $\begin{array}{l}\text { Stężenie kreatyniny w surowicy (wraz z wyliczeniem GFR) } \\
\text { Morfologia krwi z rozmazem } \\
\text { Aminotrasferazy (AspAT, AIAT) } \\
\text { Elektrolity (sód, potas, magnez) } \\
\text { Badanie ogólne moczu } \\
\text { Opcjonalnie: } \\
\text { Lipidogram (cholesterol i trójglicerydy) } \\
\text { Stężenie glukozy w surowicy }\end{array}$ \\
\hline & $\begin{array}{l}\text { Co ok. I2 } \\
\text { miesięcy }\end{array}$ & $\begin{array}{l}\text { Opcjonalnie: } \\
\text { RTG płuc }\end{array}$ \\
\hline Najważniejsze dzi & a niepożądane & $\begin{array}{l}\text { Uszkodzenie funkcji nerek } \\
\text { Nadciśnienie tętnicze } \\
\text { Rozwój nowotworów skóry } \\
\text { Przerost dziąseł } \\
\text { Hipertrychoza } \\
\text { Drżenia (rzadko drgawki) } \\
\text { Uczucie zmęczenia } \\
\text { Hiperlipidemia } \\
\text { Miopatia (jeśli CyA jest stosowana łącznie ze statynami) } \\
\text { Owrzodzenia przewodu pokarmowego } \\
\text { Hiperglikemia } \\
\text { Hiperurykemia } \\
\text { Hiperkalemia } \\
\text { Hipomagnezemia }\end{array}$ \\
\hline Przeciwwskazania & względne & $\begin{array}{l}\text { Nadwrażliwość na CyA } \\
\text { Ciężkie uszkodzenie wątroby } \\
\text { Poważne infekcje } \\
\text { Ciężkie, nieuregulowane nadciśnienie tętnicze } \\
\text { Nowotwór złośliwy } \\
\text { Jednoczesne stosowanie terapii PUVA }\end{array}$ \\
\hline Przeciwwskazania & lędne & $\begin{array}{l}\text { Dna moczanowa } \\
\text { Uszkodzenie funkcji nerek } \\
\text { Choroby wątroby } \\
\text { Hiperkalemia } \\
\text { Kumulacyjna dawka PUVA > } 2000 \mathrm{~J} / \mathrm{cm}^{2} \\
\text { Jednoczesna fototerapia UVB } \\
\text { Jednoczesne stosowanie innych leków nefrotoksycznych } \\
\text { Jednoczesne stosowanie acytretyny } \\
\text { Karmienie piersią }\end{array}$ \\
\hline
\end{tabular}

dose of $2,000 \mathrm{~J} / \mathrm{cm}^{2}$ has been exceeded. Patients treated with CsA require effective photoprotection during exposure to sunlight. CsA has a wide range of interactions with other drugs. The concentration of cyclosporin A (and hence the efficacy of treatment) is reduced by antituberculosis drugs including ri-
Jeżeli wartość szacunkowego współczynnika filtracji kłębuszkowej (estimated glomerular filtration rate - eGFR) w trakcie terapii zmniejszy się o $\geq$ $25 \%$ w stosunku do wartości początkowej w więcej niż jednym oznaczeniu, należy zmniejszyć dawkę CyA o 25-50\%. Jeśli pomimo zmniejszenia daw- 
fampicin and rifabutin (isoniazid should be used for the prevention of tuberculosis), anticonvulsants (barbiturates, phenytoin, primidone, carbamazepine), antibiotics (nafcillin, intravenously administered trimethoprim, imipenem, cephalosporins and ciprofloxacin), herb of St John's wort (Hypericum perforatum), ticlopidine, cholestyramine, and laxatives (impaired gastrointestinal absorption). Glucocorticosteroids induce cytochrome P450, accelerating CsA neutralisation. Consequently, the discontinuation of glucocorticosteroids may lead to an increase in CsA concentration by as much as $25 \%$. Drugs which elevate CsA concentration, and thus increase the risk of adverse drug reactions, include calcium channel blockers (verapamil, diltiazem, nicardipine), antimycotic agents (ketoconazole, fluconazole, itraconazole), macrolides (erythromycin, clarithromycin, josamycin), ritonavir, amiodarone, carvedilol, allopurinol, bromocriptine, chloroquine, as well as grapefruit juice. There are no literature data on interactions between CsA and acitretin, but some experts are of the view that the two drugs should not be used in combination. Both agents affect the activity of the hepatic cytochrome P450, so their combination may elevate the blood concentration of CsA and potentially increase the nephrotoxicity of the drug.

\section{Acitretin}

Acitretin is the drug of choice in the therapy of generalised pustular psoriasis. It can also be used for the treatment of moderate to severe plaque psoriasis. The therapeutic dose of acitretin ranges from 0.3 to $1 \mathrm{mg} / \mathrm{kg} \mathrm{bw} /$ day. Acitretin is the only systemic drug for psoriasis recommended for combination with PUVA therapy (Re-PUVA) or UVB therapy (ReUVB) [12]. This is due to the mechanism of action of acitretin which inhibits the processes of proliferation and stimulates keratinocyte differentiation. The combination of retinoids and phototherapy shortens the duration of treatment, reduces the cumulative UV dose required to achieve the remission of skin lesions, improves the efficacy of treatment, and reduces the risk of developing malignant skin cancer in the future. Since acitretin lacks immunosuppressive activity, it can be used in HIV-infected patients after failure of topical treatment and/or UVB phototherapy [14].

Acitretin treatment can be started with high doses $(\approx 50 \mathrm{mg} /$ day) which are gradually reduced down to the minimum dose ensuring successful disease control. An alternative dosing schedule is based on low starting doses (e.g. 10-25 mg/day) with a gradual increase (by $5 \mathrm{mg}$ every 1-2 weeks) up to the maximum dose that is well tolerated by the patient. During therapy, attention should be given to the Köbner phenomenon (formation of new skin lesions), which ki leku po 2-4 tygodniach nadal nie obserwuje się normalizacji parametrów nerkowych, lek należy odstawić. Zazwyczaj w początkowej fazie zaburzenia funkcji nerek mają charakter czynnościowy i są w pełni odwracalne po redukcji dawki CyA lub po odstawieniu leku. Stwierdzenie w przeszłości wzrostu stężenia kreatyniny w wyniku stosowania CyA nie jest bezwzględnym przeciwwskazaniem do podjęcia ponownej próby leczenia, jeśli stężenie kreatyniny jest w normie. Ryzyko rozwoju nefropatii cyklosporynowej jest podwyższone w przypadku współistnienia nieuregulowanego nadciśnienia tętniczego lub innych stanów chorobowych nerek, w przypadku przyjmowania innych leków o działaniu nefrotoksycznym (zwłaszcza niesteroidowych leków przeciwzapalnych) oraz u osób w podeszłym wieku. Suplementacja magnezem może się przyczyniać do ograniczenia działania nefrotoksycznego CyA.

Nie należy stosować CyA łącznie z PUVA lub innymi metodami fototerapii, gdyż wtedy prawdopodobieństwo rozwoju nowotworu skóry znacznie się zwiększa. Powinno się bardzo ostrożnie zalecać CyA pacjentom, którzy w przeszłości otrzymali dużą liczbę naświetlań PUVA, zwłaszcza tym, u których została przekroczona dawka kumulacyjna $2000 \mathrm{~J} / \mathrm{cm}^{2}$. Pacjenci leczeni CyA powinni stosować skuteczną fotoprotekcję w czasie ekspozycji na światło słoneczne. CyA wykazuje szereg interakcji z innymi lekami. Stężenie CyA zmniejszają (a tym samym obniżają skuteczność leczenia) leki przeciwgruźlicze: ryfampicyna i ryfabutyna (w profilaktyce gruźlicy powinien być stosowany izoniazyd), leki przeciwdrgawkowe: barbiturany, fenytoina, prymidon, karbamazepina; antybiotyki: nafcylina, dożylnie podany trimetoprim, imipenem, cefalosporyny i ciprofloksacyna; ziele dziurawca zwyczajnego (Hypericum perforatum), tiklopidyna, cholestyramina i środki przeczyszczające (upośledzenie wchłaniania w przewodzie pokarmowym). Glikokortykosteroidy indukują cytochrom P450, co powoduje przyspieszoną neutralizację CyA, dlatego po odstawieniu glikokortykosteroidów stężenie CyA może wzrosnąć nawet o 25\%. Lekami zwiększającymi stężenie CyA, a tym samym zwiększającymi ryzyko wystąpienia działań niepożądanych, są m.in. blokery kanału wapniowego: werapamil, diltiazem, nikardypina; leki przeciwgrzybicze: ketokonazol, flukonazol, itrakonazol; makrolidy: erytromycyna, klarytromycyna, josamycyna; ritonawir, amiodaron, karwedilol, allopurynol, bromokryptyna i chlorochina, a także sok grapefruitowy. Nie ma danych z piśmiennictwa dotyczących interakcji CyA z acytretyną, jednak niektórzy eksperci stoją na stanowisku, że nie powinno się stosować ich łącznie. Obydwa leki wpływają na aktywność wątrobowego cytochromu P450 i ich zastosowanie łączne może po- 
may accompany hypervitaminosis A-induced dermatitis (so-called Ro-dermatitis) (table 4).

Since acitretin has strong teratogenic effects, all women of reproductive age treated with the drug must use effective methods of contraception. Acitretin metabolites are stored in fatty tissue, so pregnancy is absolutely contraindicated for 3 years after completing treatment. Men can be treated with acitretin without any restrictions relating to child conception.

Acitretin can also be used in children, but the dose of $0.5 \mathrm{mg} / \mathrm{kg}$ bw/ day should not be exceeded. Longterm treatment with the drug in children should be avoided. However, if such therapy is necessary, skeletal development must be monitored. wodować podwyższenie stężenia CyA we krwi oraz jej potencjalnie większą nefrotoksyczność.

\section{Acytretyna}

Acytretyna jest lekiem z wyboru w terapii łuszczycy krostkowej uogólnionej. Może być także stosowana w leczeniu łuszczycy plackowatej o nasileniu umiarkowanym do ciężkiego. Dawka terapeutyczna leku wynosi 0,3-1 mg/kg m.c./dobę. Acytretyna jest jedynym lekiem podawanym ogólnie w łuszczycy, który zaleca się stosować łącznie z terapią PUVA (tzw. re-PUVA) lub UVB (re-UVB) [12]. Wynika to z mechanizmu działania acytretyny, który polega na hamowaniu proliferacji i stymulowaniu różnicowania keratynocytów. Łączne

Table 4. Recommendations on the use of acitretin in psoriasis

\begin{tabular}{|c|c|}
\hline Recommended dose & $\begin{array}{l}0.3-1 \mathrm{mg} / \mathrm{kg} \text { bw/day } \\
\text { (initial dose } 10-50 \mathrm{mg} / \text { day) }\end{array}$ \\
\hline Recommended treatment period & $\begin{array}{l}\text { Long-term therapy (provided that the drug is effective and causes no } \\
\text { severe adverse reactions) }\end{array}$ \\
\hline \multirow[t]{2}{*}{$\begin{array}{l}\text { Recommended laboratory Befo } \\
\text { tests }\end{array}$} & $\begin{array}{l}\text { Pregnancy test } \\
\text { Activity of liver enzymes in serum } \\
\text { Serum cholesterol concentration } \\
\text { Serum triglyceride concentration } \\
\text { CBC with differential } \\
\text { Serum creatinine concentration } \\
\text { Optionally: } \\
\text { Serum glucose concentration } \\
\text { Creatine kinase activity }\end{array}$ \\
\hline & $\begin{array}{l}\text { Pregnancy test } \\
\text { Activity of liver enzymes (AST, ALT) in serum } \\
\text { Serum cholesterol concentration } \\
\text { Serum triglyceride concentration } \\
\text { CBC } \\
\text { Optionally: } \\
\text { Serum glucose concentration } \\
\text { Creatine kinase activity } \\
\text { Serum creatinine concentration }\end{array}$ \\
\hline Major adverse reactions & $\begin{array}{l}\text { Teratogenicity } \\
\text { Symptoms of hypervitaminosis A - xerosis, cheilitis, alopecia, dermatitis } \\
\text { Hyperlipidaemia } \\
\text { Hypersensitivity to sunlight } \\
\text { Visual disturbances: nyctalopia } \\
\text { Headaches } \\
\text { Muscle and joint pain } \\
\text { Skeletal growth disorders } \\
\text { Elevated intracranial pressure } \\
\text { Liver injury (mainly in alcohol-abusing patients) }\end{array}$ \\
\hline Absolute contraindications & $\begin{array}{l}\text { Pregnancy and pregnancy planning for up to } 3 \text { years after the end of } \\
\text { treatment } \\
\text { Breast-feeding } \\
\text { Treatment with tetracyclines } \\
\text { Alcohol addiction } \\
\text { Severe liver and/or kidney damage } \\
\text { Pancreatitis }\end{array}$ \\
\hline Relative contraindications & $\begin{array}{l}\text { Alcohol abuse } \\
\text { Hypertriglyceridaemia } \\
\text { Diabetes } \\
\text { History of pancreatitis } \\
\text { Wearing contact lenses } \\
\text { Use of interacting drugs }\end{array}$ \\
\hline
\end{tabular}


Tabela 4. Zasady stosowania acytretyny w leczeniu łuszczycy

\begin{tabular}{|c|c|c|}
\hline \multicolumn{2}{|c|}{ Rekomendowana dawka } & $\begin{array}{l}\text { 0,3-I mg/kg m.c./dobę } \\
\text { (dawka początkowa } 10-50 \text { mg/dobę) }\end{array}$ \\
\hline \multicolumn{2}{|c|}{ Rekomendowany okres terapii } & $\begin{array}{l}\text { Długotrwale (jeśli lek jest skuteczny i nie stwierdza się poważnych działań } \\
\text { niepożądanych) }\end{array}$ \\
\hline \multirow[t]{2}{*}{$\begin{array}{l}\text { Zalecane badania } \\
\text { laboratoryjne }\end{array}$} & Przed leczeniem & $\begin{array}{l}\text { Test ciążowy } \\
\text { Aktywność enzymów wątrobowych w surowicy } \\
\text { Stężenie cholesterolu w surowicy } \\
\text { Stężenie trójglicerydów w surowicy } \\
\text { Morfologia krwi z rozmazem } \\
\text { Stężenie kreatyniny w surowicy } \\
\text { Opcjonalnie: } \\
\text { Stężenie glukozy w surowicy } \\
\text { Aktywność kinazy kreatynowej }\end{array}$ \\
\hline & Co I-3 miesiące & $\begin{array}{l}\text { Test ciążowy } \\
\text { Aktywność enzymów wątrobowych (AspAT, AIAT) w surowicy } \\
\text { Stężenie cholesterolu w surowicy } \\
\text { Stężenie trójglicerydów w surowicy } \\
\text { Morfologia krwi } \\
\text { Opcjonalnie: } \\
\text { Stężenie glukozy w surowicy } \\
\text { Aktywność kinazy kreatynowej } \\
\text { Stężenie kreatyniny w surowicy }\end{array}$ \\
\hline \multicolumn{2}{|c|}{ Najważniejsze działania niepożądane } & $\begin{array}{l}\text { Teratogenność } \\
\text { Objawy hiperwitaminozy A - suchość skóry, zapalenie czerwieni } \\
\text { wargowej, łysienie, zapalenie skóry } \\
\text { Hiperlipidemia } \\
\text { Nadwrażliwość na światło słoneczne } \\
\text { Zaburzenia widzenia - ślepota zmierzchowa } \\
\text { Bóle głowy } \\
\text { Bóle mięśniowo-kostne } \\
\text { Zaburzenia wzrastania kośćca } \\
\text { Wzrost ciśnienia śródczaszkowego } \\
\text { Uszkodzenie wątroby (głównie u pacjentów nadużywających alkoholu) }\end{array}$ \\
\hline \multicolumn{2}{|c|}{ Przeciwwskazania bezwzględne } & $\begin{array}{l}\text { Ciąża i planowanie ciąży do } 3 \text { lat po zakończeniu leczenia } \\
\text { Karmienie piersią } \\
\text { Stosowanie tetracyklin } \\
\text { Uzależnienie od alkoholu } \\
\text { Poważne uszkodzenie wątroby i/lub nerek } \\
\text { Zapalenie trzustki }\end{array}$ \\
\hline \multicolumn{2}{|c|}{ Przeciwwskazania względne } & $\begin{array}{l}\text { Nadużywanie alkoholu } \\
\text { Hipertrójglicerydemia } \\
\text { Cukrzyca } \\
\text { Zapalenie trzustki w przeszłości } \\
\text { Noszenie soczewek kontaktowych } \\
\text { Stosowanie leków wchodzących w interakcje }\end{array}$ \\
\hline
\end{tabular}

Combined treatment with acitretin and cholesterol-lowering drugs (statins) may lead to rhabdomyolysis. Also, patients using acitretin should not receive concomitant treatment with tetracycline antibiotics. Major adverse drug reactions and contraindications to acitretin treatment are listed in table 4.

\section{Systemic glucocorticosteroids}

Systemic glucocorticosteroids are not recommended in patients with psoriasis vulgaris because drugs of this group are associated with the risk of inducing generalised pustular psoriasis, especially after discontinuation of treatment. Low doses of glucocorticosteroids (not exceeding the equivalent of $15 \mathrm{mg}$ of stosowanie retinoidów $\mathrm{z}$ fototerapią skraca czas leczenia, ogranicza całkowitą dawkę UV niezbędną do uzyskania remisji zmian skórnych, poprawia skuteczność leczenia oraz zmniejsza ryzyko powstawania nowotworów złośliwych skóry w przyszłości. Ze względu na brak działania immunosupresyjnego acytretyna może być stosowana u chorych zakażonych wirusem HIV $\mathrm{w}$ przypadku niepowodzenia leczenia miejscowego i/lub fototerapii UVB [14].

Leczenie acytretyną można rozpocząć od dużych dawek ( $\approx 50 \mathrm{mg} /$ dobę) ze stopniową redukcją do minimalnej dawki skutecznie kontrolującej chorobę lub rozpocząć od małych dawek (10-25 mg/dobę), które następnie są stopniowo zwiększane (o 5 mg co 1- 
prednisone) can be used in the therapy of psoriatic arthritis if the potential benefits of treatment outweigh the possible risk of adverse reactions. Short-acting glucocorticosteroids administered systemically (e.g. hydrocortisone) can be used on an ad hoc basis for the treatment of the most severe forms of psoriasis (psoriatic erythroderma, generalised pustular psoriasis) until the achievement of therapeutic effects induced by other systemic drugs.

\section{Apremilast}

Apremilast is an oral phosphodiesterase-4 (PDE-4) inhibitor inducing immunomodulatory effects. The drug is effective in the treatment of both skin and joint lesions in patients with psoriasis $[15,16]$. Apremilast is indicated for the therapy of moderate to severe psoriasis vulgaris in adult patients. In psoriatic arthritis, the drug can be used either in monotherapy or in combination with other disease-modifying antirheumatic drugs. The recommended dose of apremilast is $30 \mathrm{mg}$ twice a day, to be taken orally (the starting dose is $2 \times 10 \mathrm{mg}$, and it is increased daily by $10 \mathrm{mg}$ until the target dose is reached). The dose of the drug should be reduced to $30 \mathrm{mg}$ once daily in patients with severe renal failure [12].

The most common adverse reactions induced by apremilast include nausea, diarrhoea, and body weight loss. As a consequence, underweight patients should regularly monitor their body weight at the start of treatment. Before the initiation of therapy with apremilast, pregnancy should be excluded, and women of reproductive age should use effective methods of contraception. Patients considered for treatment should undergo basic laboratory tests (peripheral $\mathrm{CBC}$, serum creatinine concentration, evaluation of liver enzyme activity) [12]. Major contraindications to using the drug - in addition to pregnancy and breast-feeding (because of insufficient data on the safety of such therapy) - include hypersensitivity to the drug substance or excipients, severe acute infection, and congenital galactose intolerance syndromes [12].

Apremilast represents one of the main therapeutic options for the treatment of psoriasis, but it is not currently reimbursed in Poland.

\section{Dimethyl ester of fumaric acid (dimethyl fumarate)}

Fumaric acid esters are used on a routine basis for the treatment of psoriasis vulgaris in some European countries. In Poland, dimethyl ester of fumaric acid is approved for the therapy of psoriasis. It is a pro-drug which converts rapidly to monomethyl fumarate, inducing antiinflammatory and immunomodulatory effects. The drug is not currently reimbursed in Poland.
2 tygodnie) do maksymalnej dawki dobrze tolerowanej przez pacjenta. $W$ trakcie terapii należy zwrócić uwage na zjawisko koebneryzacji (wysiewu nowych zmian skórnych), które może wystąpić w razie pojawienia się zapalenia skóry związanego z hiperwitaminozą A (tzw. Ro-dermatitis) (tab. 4).

Acytretyna jest lekiem silnie teratogennym i wszystkie kobiety w okresie reprodukcyjnym, które ją przyjmują, muszą stosować skuteczne metody antykoncepcji. Ponieważ metabolity acytretyny są magazynowane w tkance tłuszczowej, zachodzenie w ciążę jest przeciwwskazane przez 3 lata od zakończenia leczenia. Mężczyźni mogą stosować acytretynę bez restrykcji dotyczących poczęcia dziecka.

Acytretyna może być stosowana u dzieci, ale nie zaleca się przekraczania dawki $0,5 \mathrm{mg} / \mathrm{kg}$ m.c./dobę. Powinno się unikać długotrwałego stosowania leku u dzieci. W przypadku takiej konieczności należy monitorować rozwój kośćca.

Łączne stosowanie acytretyny z lekami zmniejszającymi stężenie cholesterolu (statynami) może prowadzić do rabdomiolizy. Osoby stosujące acytretynę nie powinny przyjmować jednocześnie antybiotyków z grupy tetracyklin. Podstawowe działania niepożądane acytretyny i przeciwwskazania do jej stosowania zamieszczono w tabeli 4 .

\section{Glikokortykosteroidy stosowane ogólnie}

Nie zaleca się stosowania glikokortykosteroidów ogólnie u pacjentów z łuszczycą zwyczajną, gdyż wiąże się to z ryzykiem wywołania uogólnionej łuszczycy krostkowej, zwłaszcza po odstawieniu leczenia. Małe dawki glikokortykosteroidów (nieprzekraczające odpowiednika $15 \mathrm{mg}$ prednizonu) mogą być jednak stosowane w przypadku łuszczycy stawowej, jeżeli ewentualna korzyść płynąca z takiego leczenia przewyższa potencjalne ryzyko wystąpienia działań niepożądanych. Krótko działające glikokortykosteroidy podawane ogólnie (np. hydrokortyzon) mogą być stosowane doraźnie w terapii najcięższych postaci łuszczycy (erytrodermii łuszczycowej, uogólnionej łuszczycy krostkowej) do czasu uzyskania efektu terapeutycznego innych leków ogólnych.

\section{Apremilast}

Apremilast jest doustnym inhibitorem fosfodiesterazy 4 (PDE-4) o działaniu immunomodulującym. Wykazuje skuteczność w terapii zarówno zmian skórnych, jak i stawowych w łuszczycy $[15,16]$. Apremilast jest wskazany w leczeniu łuszczycy zwykłej o nasileniu umiarkowanym do ciężkiego u osób dorosłych. W łuszczycowym zapaleniu stawów może być podawany w monoterapii lub łącznie z innymi lekami przeciwreumatycznymi modyfikującymi przebieg choroby. Zalecana dawka apremilastu to $30 \mathrm{mg} 2$ razy na dobę w podaniu doustnym (początkowo 
However, it represents one of the main therapeutic options for the treatment of psoriasis. The efficacy of dimethyl ester of fumaric acid is comparable to that of methotrexate. The drug can be used for both induction and maintenance therapies. On account of gastrointestinal disorders which are occasionally observed in patients especially at the onset of treatment, the recommended starting dose is $30 \mathrm{mg} /$ day, and it should be gradually increased up to a level that ensures effective disease control. The maximum daily dose of dimethyl ester of fumaric acid in the treatment of psoriasis is $720 \mathrm{mg}$ (table 5) [17].

The most common adverse reactions of fumaric acid esters include nausea and diarrhoea, and they are far more common when the dose of the drug is increased too fast. Patients should be informed about the potential effects of the drug on the gastrointestinal system in order to reduce the risk of patients discontinuing therapy because of adverse drug reactions. Other common adverse reactions include sudden facial erythema as well as leukopaenia and lymphopenia. Consequently, treatment should not be commenced in patients with leukopaenia below $3.0 \times 10^{9} / 1$ or lymphopaenia below $1.0 \times 10^{9} / 1$. Despite the risk of adverse reactions discussed above, dawka wynosi 2 razy $10 \mathrm{mg}$ i zwiększana jest codziennie o $10 \mathrm{mg}$ do dawki docelowej). Dawkowanie apremilastu należy zmniejszyć do 30 mg raz na dobę u pacjentów z ciężką niewydolnością nerek [12].

Do najczęstszych działań niepożądanych apremilastu należą nudności, biegunka oraz redukcja masy ciała. $Z$ tego powodu pacjenci z niedowagą na początku leczenia powinni regularnie monitorować masę ciała. Przed rozpoczęciem stosowania apremilastu należy wykluczyć ciążę, a kobiety w wieku rozrodczym powinny stosować skuteczną antykoncepcję. Pacjenci kwalifikowani do leczenia apremilastem powinni mieć wykonane podstawowe badania laboratoryjne (morfologia krwi obwodowej, stężenie kreatyniny w surowicy, oznaczenie aktywności enzymów wątrobowych) [12]. Najważniejsze przeciwwskazania do stosowania apremilastu, poza ciążą i okresem karmienia piersią (z uwagi na brak wystarczających danych dotyczących bezpieczeństwa), to m.in. nadwrażliwość na lek lub substancje pomocnicze, ciężka ostra infekcja oraz wrodzone zespoły nietolerancji galaktozy [12].

Obecnie lek ten nie jest objęty refundacją, jednak stanowi jedną z podstawowych opcji terapeutycznych w łuszczycy.

Table 5. Recommendations on the use of dimethyl ester of fumaric acid in psoriasis

\begin{tabular}{|c|c|c|}
\hline \multicolumn{2}{|l|}{ Recommended starting dose } & $30 \mathrm{mg} /$ day, gradual dose increase to a level ensuring successful disease control \\
\hline \multicolumn{2}{|c|}{ Recommended maintenance dose } & 120-720 mg/day (the dose depends on the tolerance and clinical effect) \\
\hline \multicolumn{2}{|c|}{ Recommended treatment period } & $\begin{array}{l}\text { Long-term therapy (provided that the drug is effective and causes no severe } \\
\text { adverse reactions) }\end{array}$ \\
\hline \multirow[t]{2}{*}{$\begin{array}{l}\text { Recommended laboratory } \\
\text { tests }\end{array}$} & $\begin{array}{l}\text { Before starting } \\
\text { treatment }\end{array}$ & $\begin{array}{l}\text { Pregnancy test } \\
\text { Activity of liver enzymes in serum } \\
\text { CBC with differential } \\
\text { Serum creatinine concentration } \\
\text { General urine analysis }\end{array}$ \\
\hline & Every 3 months & $\begin{array}{l}\text { Activity of liver enzymes in serum } \\
\text { CBC } \\
\text { Serum creatinine concentration } \\
\text { General urine analysis }\end{array}$ \\
\hline
\end{tabular}

Tabela 5. Zasady stosowania estru dimetylowego kwasu fumarowego w leczeniu łuszczycy

\begin{tabular}{|c|c|c|}
\hline \multicolumn{2}{|c|}{ Rekomendowana dawka początkowa } & $\begin{array}{l}30 \text { mg/dobę, stopniowe zwiększanie dawkowania do dawki skutecznie } \\
\text { kontrolującej chorobę }\end{array}$ \\
\hline \multicolumn{2}{|c|}{ Rekomendowana dawka podtrzymująca } & I 20-720 mg/dobę (dawka zależy od tolerancji i efektu klinicznego) \\
\hline \multicolumn{2}{|c|}{ Rekomendowany okres terapii } & $\begin{array}{l}\text { Długotrwale (jeśli lek jest skuteczny i nie stwierdza się poważnych działań } \\
\text { niepożądanych) }\end{array}$ \\
\hline \multirow[t]{2}{*}{$\begin{array}{l}\text { Zalecane badania } \\
\text { laboratoryjne }\end{array}$} & Przed leczeniem & $\begin{array}{l}\text { Test ciążowy } \\
\text { Aktywność enzymów wątrobowych w surowicy } \\
\text { Morfologia krwi z rozmazem } \\
\text { Stężenie kreatyniny w surowicy } \\
\text { Badanie ogólne moczu }\end{array}$ \\
\hline & Co 3 miesiące & $\begin{array}{l}\text { Aktywność enzymów wątrobowych w surowicy } \\
\text { Morfologia krwi } \\
\text { Stężenie kreatyniny w surowicy } \\
\text { Badanie ogólne moczu }\end{array}$ \\
\hline
\end{tabular}


therapy based on esters of fumaric acid is rarely associated with severe adverse reactions.

\section{Biological drugs}

Biological drugs, which have a targeted effect on the selected stage of the immune response, exhibit more selective therapeutic activity than conventional antipsoriatic drugs. As a result, high therapeutic efficacy can be achieved at a relatively low risk of developing adverse reactions. Biological treatment is a suitable option in patients diagnosed with moderate to severe plaque psoriasis, arthritic psoriasis or another form of psoriasis which fails to respond to previous treatment. Therapy should be continued on a long-term basis for as long as the therapeutic benefits outweigh potential risks associated with longterm biological therapy. A decision to interrupt/ discontinue biological therapy, similarly to other antipsoriatic treatment modalities, should be made by the attending physician after consultation with the patient. Table 6 lists the main diagnostic tests which should be performed to assess patient eligibility for biological therapy and to monitor the course of treatment.

Patients with latent tuberculosis can be treated with biological drugs, provided that tuberculosis chemoprophylaxis is provided to the patient (isoniazid, rifampicin, or both drugs concurrently) at least a month prior to the commencement of biological therapy. The duration of prophylactic treatment depends on the selected antituberculosis drug. Biological drugs may contribute to the reactivation of hepatitis B and C, so infected individuals should be provided with appropriate prophylactic antiviral treatment, if necessary, before starting biological treatment.

Also, biological drugs can be prescribed with caution to women during pregnancy and breast-feeding, provided that benefits of such treatment outweigh the potential risk of adverse reactions. Certolizumab pegol should be considered as the drug of first choice in pregnant women with severe psoriasis requiring biological treatment, as the drug does not cross the placenta [18]. Patients receiving biological treatment should not be vaccinated with live vaccines.

\section{Tumour necrosis factor inhibitors}

A total of 5 biological drugs inhibiting the tumour necrosis factor (TNF) are currently available in Poland. The selection of a TNF inhibitor should be based on the patients' history of treatment and their therapeutic preferences, the attending physician's experience, and special circumstances regarding a particular patient. Even though all available drugs inhibit TNF, their structure, mechanism of action and

\section{Ester dimetylowy kwasu fumarowego (fumaran dimetylu)}

Estry kwasu fumarowego są rutynowo stosowane w leczeniu łuszczycy zwykłej w niektórych krajach europejskich. W Polsce do leczenia łuszczycy zarejestrowany jest ester dimetylowy kwasu fumarowego, który jest prolekiem szybko przekształcającym się do monometylofumaranu i ma działanie przeciwzapalne i immunomodulujące. Obecnie nie jest refundowany. Lek ten stanowi jednak jedną z istotnych opcji terapeutycznych w łuszczycy. Skuteczność estru dimetylowego kwasu fumarowego jest porównywalna z MTX. Ze względu na występujące niekiedy dolegliwości żołądkowo-jelitowe, zwłaszcza na początku leczenia, zaleca się rozpoczynanie terapii od dawki $30 \mathrm{mg} /$ dobę z następczym sukcesywnym zwiększaniem dawkowania do dawki skutecznie kontrolującej przebieg choroby. Maksymalna dobowa dawka estru dimetylowego kwasu fumarowego w leczeniu łuszczycy wynosi $720 \mathrm{mg}$ (tab. 5) [17].

Do najczęstszych działań niepożądanych estrów kwasu fumarowego należą nudności i biegunka, przy czym występują one zdecydowanie częściej, jeśli dawka leku jest zwiększana zbyt szybko. Poinformowanie pacjenta o potencjalnym wpływie leku na przewód pokarmowy pozwala ograniczyć ryzyko zaprzestania leczenia przez pacjenta z powodu działań niepożądanych. Do innych częstych działań niepożądanych należą nagły rumień twarzy, a także leukopenia i limfopenia, dlatego nie należy rozpoczynać leczenia w przypadku stwierdzenia leukopenii poniżej 3,0 × 109/1 lub limfopenii poniżej $1,0 \times 10^{9} / 1$. Stosowanie estrów kwasu fumarowego rzadko wiąże się z wystąpieniem poważnych objawów niepożądanych.

\section{Leki biologiczne}

Leki biologiczne poprzez celowany wpływ na wybrany etap reakcji immunologicznej mają bardziej selektywne działanie terapeutyczne niż klasyczne leki przeciwłuszczycowe. Umożliwia to uzyskanie wysokiej skuteczności leczniczej przy stosunkowo niewielkim ryzyku wystąpienia działań niepożądanych. Leczenie pacjentów, którzy mają wskazania do tej metody terapeutycznej, powinno być rozpoczęte możliwie szybko. Do leczenia biologicznego kwalifikują się pacjenci, u których rozpoznano łuszczycę plackowatą o nasileniu umiarkowanym do ciężkiego, łuszczycę stawową lub inną postać łuszczycy, która nie reaguje na dotychczas stosowane leczenie. Leczenie powinno być długotrwałe, jeśli uzyskiwane korzyści przeważają nad ewentualnym ryzykiem długoterminowej terapii biologicznej. Decyzję o przerwaniu lub zakończeniu leczenia biologicznego, podobnie jak w przypadku innych metod terapii przeciwłuszczycowej, powinien podejmować lekarz 
Table 6. Diagnostic tests recommended during biological treatment

\begin{tabular}{ll} 
Before starting & CBC with differential \\
treatment & Liver enzymes (AST, ALT, GGTP) \\
& Serum creatinine concentration \\
& CRP or ESR \\
& Pregnancy test \\
Viral hepatitis tests (HBs antigen, anti- & HCV antibodies) \\
& Serum anti-HIV antibody test \\
& Radiological lung examination \\
& Screening for tuberculosis \\
& (e.g. Quantiferon ${ }^{\circledR}$ TB Gold) \\
& Optionally: \\
& Serum antinuclear antibodies (ANA) \\
& Laryngologic examination \\
& Dental examination \\
& Gynaecological examination \\
\hline Approximately every & CBC with differential \\
& Liver tests (AST, ALT, GGTP) \\
& Serum creatinine concentration \\
& CRP or ESR \\
\hline months & Optionally: \\
& Radiological lung examination \\
& Screening for tuberculosis (e.g. \\
Quantiferon ${ }^{\circledR}$ TB Gold)
\end{tabular}

clinical efficacy vary (table 7). Also, a range of biosimilar drugs are already available for some of the TNF inhibitors. Their introduction into treatment regimens has markedly reduced the costs of therapy. Importantly, TNF inhibitors should no longer be as innovative drugs, but as a therapeutic standard that should be available to all patients with moderate to severe psoriasis, preferably as part of treatment provided on an outpatient basis.

Infliximab is a chimeric human-mouse IgG-class monoclonal antibody exhibiting high affinity to both soluble and transmembrane forms of TNF. Treatment with infliximab leads to PASI-75 improvement in $80 \%$ of patients as early as at 10 weeks of therapy, and in $61 \%$ of patients the therapeutic effect is maintained until 50 weeks of treatment. The drug is characterised by a rapid onset of clinical efficacy,
Tabela 6. Badania diagnostyczne zalecane w trakcie leczenia biologicznego

\begin{tabular}{ll} 
Przed leczeniem & Morfologia krwi z rozmazem \\
& Enzymy wątrobowe (AspAT, AIAT, GGTP) \\
& Stężenie kreatyniny w surowicy \\
& CRP lub OB \\
& Test ciążowy \\
& Badania wirusologiczne wątroby (antygen \\
& HBs, przeciwciała anty-HCV) \\
& Badanie przeciwciał anty-HIV w surowicy \\
& Badanie radiologiczne płuc \\
& Badanie przesiewowe w kierunku gruźlicy \\
& (np. Quantiferon ${ }^{\circledR}$ TB Gold) \\
& Opcjonalnie: \\
& Przeciwciała przeciwjądrowe \\
& W surowicy (ANA) \\
& Badanie laryngologiczne \\
& Badanie stomatologiczne \\
& Badanie ginekologiczne \\
\hline Co ok. 3 miesiące & Morfologia krwi z rozmazem \\
& Próby wątrobowe (AspAT, AIAT, GGTP) \\
& Stężenie kreatyniny w surowicy \\
& CRP lub OB \\
\hline Opcjonalnie: \\
\hline Raz w roku & Badanie radiologiczne płuc \\
& Badanie przesiewowe w kierunku \\
gruźlicy (np. Quantiferon ${ }^{\circledR}$ TB Gold)
\end{tabular}

prowadzący w porozumieniu z pacjentem. W tabeli 6 przedstawiono podstawowe badania diagnostyczne, które powinny być wykonane przy kwalifikacji pacjenta do leczenia biologicznego oraz w czasie monitorowania terapii.

Pacjenci z utajoną gruźlicą mogą być leczeni biologicznie pod warunkiem wdrożenia chemoprofilaktyki gruźlicy izoniazydem, ryfampicyną lub obydwoma tymi lekami jednocześnie na przynajmniej miesiąc przed rozpoczęciem terapii biologicznej. Czas leczenia profilaktycznego zależy od wybranego leku przeciwgruźliczego. Leki biologiczne mogą się przyczyniać do reaktywacji wirusowego zapalenia wątroby typu $\mathrm{B}$ lub C, dlatego w razie konieczności u osób zakażonych przed rozpoczęciem leczenia biologicznego należy wdrożyć odpowiednie profilaktyczne leczenie przeciwwirusowe. 
Table 7. Characteristics of biological drugs inhibiting tumour necrosis factor $\alpha$

\begin{tabular}{|c|c|c|c|c|c|}
\hline Parameter & Infliximab & Etanercept & Adalimumab & Golimumab & $\begin{array}{c}\text { Certolizumab } \\
\text { pegol }\end{array}$ \\
\hline Drug type & $\begin{array}{l}\text { Chimeric (human- } \\
\text { mouse) monoclonal } \\
\text { antibody }\end{array}$ & Fusion protein & $\begin{array}{l}\text { Human monoclonal } \\
\text { antibody }\end{array}$ & $\begin{array}{l}\text { Human monoclonal } \\
\text { antibody }\end{array}$ & $\begin{array}{l}\text { Fab fragment of } \\
\text { antibody conjugated } \\
\text { to polyethylene } \\
\text { glycol (PEG) }\end{array}$ \\
\hline Approved indications & $\begin{array}{l}\text { Plaque psoriasis } \\
\text { Psoriatic arthritis }\end{array}$ & $\begin{array}{l}\text { Plaque psoriasis } \\
\text { Psoriatic arthritis }\end{array}$ & $\begin{array}{l}\text { Plaque psoriasis } \\
\text { Psoriatic arthritis }\end{array}$ & Psoriatic arthritis & $\begin{array}{l}\text { Plaque psoriasis } \\
\text { Psoriatic arthritis }\end{array}$ \\
\hline $\begin{array}{l}\text { Approved dosage } \\
\text { regimen }\end{array}$ & $\begin{array}{c}5 \mathrm{mg} / \mathrm{kg} \text { bw at } \\
\text { weeks } 0,2 \text { and } 6 \text {, } \\
\text { followed by every } \\
8 \text { weeks (unless } \\
\text { contraindicated, } \\
\text { the drug should be } \\
\text { used in combination } \\
\text { with methotrexate) }\end{array}$ & $\begin{array}{c}2 \times 50 \mathrm{mg} / \text { week } \\
\text { (for the initial } \\
3 \text { months) or } \\
2 \times 25 \mathrm{mg} / \text { week } \\
\text { or I } \times 50 \mathrm{mg} / \\
\text { week }\end{array}$ & $\begin{array}{l}80 \mathrm{mg} \text { at week I, } \\
40 \mathrm{mg} \text { at week } 2 \text {, } \\
\text { then } 40 \mathrm{mg} \text { every } \\
\text { other week }\end{array}$ & $50 \mathrm{mg} / \mathrm{month}$ & $\begin{array}{l}400 \mathrm{mg} \text { ( } 2 \text { injections } \\
\text { of } 200 \mathrm{mg} \text { daily) at } \\
\text { weeks } 0,2 \text { and } 4 \text {, } \\
\text { followed by } 200 \mathrm{mg} \\
\text { every } 2 \text { weeks }\end{array}$ \\
\hline Route of administration & Intravenous & Subcutaneous & Subcutaneous & Subcutaneous & Subcutaneous \\
\hline $\begin{array}{l}\text { Approved for use in } \\
\text { children with psoriasis }\end{array}$ & No & $\begin{array}{l}\text { From the age of } \\
6 \text { years (dose: } \\
0.8 \mathrm{mg} / \mathrm{kg} \text { bw/ } \\
\text { week) }\end{array}$ & $\begin{array}{c}\text { From the age of } \\
4 \text { years (dose: } \\
0.8 \mathrm{mg} / \mathrm{kg} \text { per week } \\
\text { for the first } \\
2 \text { weeks, followed } \\
\text { by every } 2 \text { weeks) }\end{array}$ & No & No \\
\hline
\end{tabular}

Tabela 7. Charakterystyka leków biologicznych blokujących czynnik martwicy nowotworów $\alpha$

\begin{tabular}{|c|c|c|c|c|c|}
\hline Parametr & Infliksymab & Etanercept & Adalimumab & Golimumab & $\begin{array}{c}\text { Certolizumab } \\
\text { pegol }\end{array}$ \\
\hline Typ leku & $\begin{array}{l}\text { Chimeryczne } \\
\text { (mysio-ludzkie) } \\
\text { przeciwciało } \\
\text { monoklonalne }\end{array}$ & Białko fuzyjne & $\begin{array}{c}\text { Ludzkie } \\
\text { przeciwciało } \\
\text { monoklonalne }\end{array}$ & $\begin{array}{l}\text { Ludzkie } \\
\text { przeciwciało } \\
\text { monoklonalne }\end{array}$ & $\begin{array}{c}\text { Fragment Fab prze- } \\
\text { ciwciała sprzęgnięty } \\
\text { z polietylenogliko- } \\
\text { lem (PEG) }\end{array}$ \\
\hline $\begin{array}{l}\text { Wskazanie } \\
\text { rejestracyjne }\end{array}$ & $\begin{array}{c}\text { Łuszczyca } \\
\text { plackowata } \\
\text { Łuszczycowe } \\
\text { zapalenie stawów }\end{array}$ & $\begin{array}{c}\text { Łuszczyca } \\
\text { plackowata } \\
\text { Łuszczycowe } \\
\text { zapalenie stawów }\end{array}$ & $\begin{array}{c}\text { Łuszczyca } \\
\text { plackowata } \\
\text { Łuszczycowe } \\
\text { zapalenie stawów }\end{array}$ & $\begin{array}{c}\text { Łuszczycowe } \\
\text { zapalenie stawów }\end{array}$ & $\begin{array}{c}\text { Łuszczyca } \\
\text { plackowata } \\
\text { Łuszczycowe } \\
\text { zapalenie stawów }\end{array}$ \\
\hline $\begin{array}{l}\text { Dawkowanie } \\
\text { rejestracyjne }\end{array}$ & $\begin{array}{c}5 \text { mg/kg m.c. } \\
\text { w tygodniu 0, } 2 . \\
\text { i } 6 . \text {, a następnie } \\
\text { co } 8 \text { tygodni } \\
\text { (jeśli nie ma } \\
\text { przeciwwskazań, } \\
\text { lek należy stosować } \\
\text { z metotreksatem) }\end{array}$ & $\begin{array}{c}2 \times 50 \text { mg/tydzień } \\
\text { (przez pierwsze } \\
3 \text { miesiące) lub } \\
2 \times 25 \mathrm{mg} / \text { tydzień } \\
\text { lub I } \times 50 \mathrm{mg} / \\
\text { tydzień }\end{array}$ & $\begin{array}{c}80 \mathrm{mg} \\
\text { w pierwszym } \\
\text { tygodniu, } 40 \mathrm{mg} \\
\text { w drugim tygodniu, } \\
\text { a następnie } 40 \mathrm{mg} \\
\text { co } 2 \text { tygodnie }\end{array}$ & $50 \mathrm{mg} / \mathrm{miesiąc}$ & $\begin{array}{c}400 \mathrm{mg} \\
\text { (2 wstrzyknięcia } \\
\text { po } 200 \mathrm{mg} / \text { dobę) } \\
\text { przyjmowane } \\
\text { w tygodniu 0, } 2 . \\
\text { i } 4 ., \text { następnie } \\
200 \text { mg co } \\
2 \text { tygodnie }\end{array}$ \\
\hline Droga podania & Dożylnie & Podskórnie & Podskórnie & Podskórnie & Podskórnie \\
\hline $\begin{array}{l}\text { Zarejestrowany do } \\
\text { stosowania u dzieci } \\
\text { z łuszczycą }\end{array}$ & Nie & $\begin{array}{l}\text { Od 6. roku życia } \\
\text { (dawka: } 0,8 \text { mg/ } \\
\text { kg m.c./tydzień) }\end{array}$ & $\begin{array}{c}\text { Od 4. roku życia } \\
\text { (dawka: 0,8 mg/kg } \\
\text { co tydzień przez } \\
\text { pierwsze } 2 \text { tygodnie, } \\
\text { następnie co } \\
2 \text { tygodnie) }\end{array}$ & Nie & $\mathrm{Nie}$ \\
\hline
\end{tabular}

but some patients lose response to treatment over the course of therapy. Consequently, combination treatment with infliximab and MTX is recommended in order to prevent the formation of antibodies neutralising the drug.

Etanercept is a recombinant fusion protein consisting of dimeric soluble form of tumour necrosis
Leki biologiczne mogą być z ostrożnością stosowane u kobiet w ciąży i w okresie karmienia piersią, pod warunkiem że korzyść z takiego leczenia przewyższa ryzyko wystąpienia ewentualnych działań niepożądanych (szczegółowe dane na temat bezpieczeństwa stosowania leków w ciąży zestawiono w części 1). W przypadku kobiet w ciąży z ciężką łuszczycą wy- 
factor receptor-2 (TNFR2/p75) and the Fc fragment of human IgG1-class antibody. The efficacy of the drug based on the PASI-75 parameter is estimated at approximately $47 \%$ at 12 weeks, and $59 \%$ at 24 weeks of treatment, though the first positive effects are normally seen between weeks 4 and 8 of treatment. Adalimumab is the first human monoclonal antibody with a targeted action against TNF. The protein attaches both to soluble and membrane-bound $\mathrm{TNF}$, thus blocking the interaction between TNF and the surface receptors p55 and p75. The efficacy of adalimumab in clinical studies, expressed as the PASI-75 score, was estimated at $71 \%$ at 16 weeks, and $83 \%$ at 48 weeks. In turn, PASI-90 response at 48 weeks was achieved in $58 \%$ of patients, and PASI-100 in $32 \%$ of study subjects [19]. The proportion of severe adverse reactions during adalimumab treatment was low (less than $2 \%$ ), comparable to the placebo group [19].

Certolizumab pegol is a Fab fragment of antibody conjugated to polyethylene glycol (PEG). As mentioned above, recent studies indicate that the drug practically does not cross the placenta, so the use of certolizumab pegol may be used in pregnany when clearly clinically indicated [18]. However, in the Summary of Product Characteristics, the manufacturer recommends that women of reproductive age use appropriate methods of contraception, both during treatment and for at least 5 months after taking the last dose, to prevent pregnancy.

\section{Interleukin- 17 inhibitors}

Two monoclonal antibodies directly inhibiting IL-17A (ixekizumab and secukinumab) and a monoclonal antibody blocking the IL-17 receptor (brodalumab) are currently approved in Europe for the treatment of psoriasis (table 8). Bimekizumab, which has inhibitory effect towards both IL-17A and IL-17F, will probably soon be approved for treatment as well. The efficacy of IL-17 inhibitors has been confirmed in a number of multicentre clinical studies in a population of several thousand patients [20-22]. The efficacy of treatment after 12-16 weeks is approximately $76-93 \%$ for PASI 75, 54-79\% for PASI-90 and 24-44\% for PASI-100, according to SPC data.

Drugs of this group have a favourable safety profile. However, an increased propensity for fungal infections can be observed in patients during therapy, particularly mild to moderate cutaneous and mucosal candidiasis, which is attributable to the mechanism of action of this group of drugs. In the vast majority of cases such infections were successfully treated with standard antifungal therapy and did not require interruption of anti-psoriatic treatment. magającą leczenia biologicznego w pierwszej kolejności należy rozważyć zasadność stosowania certolizumabu pegol, który nie przenika przez łożysko [18]. Chorzy leczeni biologicznie nie powinni być szczepieni żywymi szczepionkami.

\section{Leki blokujące czynnik martwicy nowotworu}

Obecnie w Polsce dostępnych jest 5 różnych leków biologicznych blokujących czynnik martwicy nowotworu (TNF). Dobór leku blokującego TNF powinien uwzględniać dotychczasowe leczenie, preferencje chorego, doświadczenie lekarza prowadzącego leczenie oraz specyficzną sytuację pacjenta. Mimo że wszystkie leki hamują TNF, ich budowa, mechanizm działania i efektywność kliniczna są odmienne (tab. 7). Obecnie w przypadku niektórych inhibitorów TNF dostępnych jest już szereg preparatów biopodobnych. Wprowadzenie ich do lecznictwa spowodowało znaczące zmniejszenie kosztów leczenia. Należy podkreślić, że inhibitory TNF stosowane są w medycynie od ponad 20 lat i nie powinny być już traktowane jako leki innowacyjne, ale jako standard terapeutyczny, który powinien być dostępny dla pacjentów chorych na łuszczycę umiarkowaną do ciężkiej, również $\mathrm{w}$ ramach leczenia $\mathrm{w}$ lecznictwie otwartym.

Infliksymab jest chimerycznym mysio-ludzkim przeciwciałem monoklonalnym klasy IgG o dużym powinowactwie zarówno do rozpuszczalnej, jak i transbłonowej formy TNF. Leczenie infliksymabem prowadzi do poprawy PASI-75 u 80\% chorych już w 10. tygodniu terapii, a u $61 \%$ leczonych efekt terapeutyczny utrzymuje się do 50. tygodnia leczenia. Preparat ten odznacza się bardzo szybkim uzyskiwaniem skuteczności klinicznej, jednak w czasie trwania terapii u części pacjentów występuje utrata odpowiedzi na leczenie. Zaleca się zatem, aby infliksymab stosować razem z MTX, gdyż może to zmniejszać tendencję do tworzenia się przeciwciał neutralizujących lek.

Etanercept jest rekombinowanym białkiem fuzyjnym składającym się z dimerycznego rozpuszczalnego receptora 2 dla czynnika martwicy nowotworów (TNFR2/p75) i fragmentu Fc ludzkiego przeciwciała klasy IgG1. Skuteczność leku mierzona parametrem PASI-75 ocenia się na około $47 \%$ w 12. tygodniu i 59\% w 24. tygodniu terapii, choć pierwsze pozytywne efekty widoczne są zazwyczaj między 4. a 8. tygodniem leczenia. Adalimumab jest pierwszym ludzkim przeciwciałem monoklonalnym skierowanym przeciwko TNF. Białko to przyłącza się zarówno do rozpuszczalnego, jak i związanego błonowego TNF, przez co blokuje interakcję pomiędzy TNF a receptorami powierzchniowym p55 i p75. Skuteczność adalimumabu w badaniach klinicznych wyrażona współczynnikiem PASI-75 została oceniona na 71\% w 16. tygodniu i 83\% w 48. tygodniu. Z kolei PASI-90 w 48. tygodniu uzyskano u 58\% chorych, a PASI-100 u 32\% [19]. Odsetek poważnych działań niepożądanych 
Table 8. Characteristics of biological interleukin- 17 inhibitors

\begin{tabular}{|c|c|c|c|}
\hline \multirow[t]{2}{*}{ Parameter } & \multicolumn{3}{|c|}{ Anti-interleukin- 17 agents } \\
\hline & Secukinumab & Ixekizumab & Brodalumab \\
\hline Drug type & $\begin{array}{c}\text { Recombinant human monoclonal } \\
\text { IgGI antibody targeted against } \\
\text { IL- I7A }\end{array}$ & $\begin{array}{l}\text { Recombinant humanised } \\
\text { monoclonal lgG4 antibody } \\
\text { targeted against IL- I7A }\end{array}$ & $\begin{array}{l}\text { Recombinant human monoclonal } \\
\text { IgG2-class antibody binding to the } \\
\text { receptor for IL- I } 7 \mathrm{~A}\end{array}$ \\
\hline Approved indications & $\begin{array}{l}\text { Plaque psoriasis } \\
\text { Psoriatic arthritis }\end{array}$ & $\begin{array}{l}\text { Plaque psoriasis, } \\
\text { Psoriatic arthritis }\end{array}$ & Plaque psoriasis \\
\hline $\begin{array}{l}\text { Dosing regimen in plaque } \\
\text { psoriasis }\end{array}$ & $\begin{array}{l}300 \text { mg at weeks } 0,1,2 \text { and } 3, \\
\text { followed by monthly maintenance } \\
\text { doses starting from week } 4\end{array}$ & $\begin{array}{c}160 \mathrm{mg} \text { at week } 0 \text {, then } 80 \mathrm{mg} \\
\text { at weeks } 2,4,6,8,10 \text { and } 12 \text {, } \\
\text { followed by } 80 \mathrm{mg} \text { maintenance } \\
\text { doses once every } 4 \text { weeks }\end{array}$ & $\begin{array}{l}210 \mathrm{mg} \text { at weeks } 0,1 \text { and } 2, \\
\text { followed by } 210 \mathrm{mg}\end{array}$ \\
\hline Route of administration & Subcutaneous & Subcutaneous & Subcutaneous \\
\hline $\begin{array}{l}\text { Approved for the } \\
\text { treatment of childhood } \\
\text { psoriasis }\end{array}$ & No & No & No \\
\hline
\end{tabular}

Tabela 8. Charakterystyka leków biologicznych blokujących interleukinę 17

\begin{tabular}{|c|c|c|c|}
\hline \multirow[t]{2}{*}{ Parametr } & \multicolumn{3}{|c|}{ Leki blokujące interleukinę I7 } \\
\hline & Sekukinumab & Iksekizumab & Brodalumab \\
\hline Typ leku & $\begin{array}{l}\text { Rekombinowane ludzkie } \\
\text { przeciwciało monoklonalne IgG I } \\
\text { skierowane przeciwko IL- I7A }\end{array}$ & $\begin{array}{l}\text { Rekombinowane humanizowane } \\
\text { przeciwciało monoklonalne lgG4 } \\
\text { skierowane przeciwko IL- I7A }\end{array}$ & $\begin{array}{l}\text { Rekombinowane ludzkie } \\
\text { przeciwciało monoklonalne } \\
\text { klasy lgG2, które wiąże się } \\
\text { z receptorem dla IL- I7A }\end{array}$ \\
\hline Wskazanie rejestracyjne & $\begin{array}{c}\text { Łuszczyca plackowata } \\
\text { Łuszczycowe zapalenie stawów }\end{array}$ & $\begin{array}{c}\text { Łuszczyca plackowata } \\
\text { Łuszczycowe zapalenie stawów }\end{array}$ & Łuszczyca plackowata \\
\hline $\begin{array}{l}\text { Dawkowanie w łuszczycy } \\
\text { plackowatej }\end{array}$ & $\begin{array}{c}300 \text { mg w tygodniu 0, I., 2. i 3., } \\
\text { a następnie comiesięczne dawki } \\
\text { podtrzymujące, począwszy od } \\
\text { tygodnia } 4 .\end{array}$ & $\begin{array}{l}\text { I } 60 \text { mg w tygodniu 0, następnie } \\
80 \text { mg w tygodniu 2., 4., 6., } \\
\text { 8., I0. i I 2., a następnie dawka } \\
\text { podtrzymująca } 80 \text { mg podawana } \\
\text { raz na } 4 \text { tygodnie }\end{array}$ & $\begin{array}{c}210 \text { mg w tygodniu } 0,1 \text {. i } 2 ., \\
\text { a następnie } 210 \mathrm{mg}\end{array}$ \\
\hline Droga podania & Podskórnie & Podskórnie & Podskórnie \\
\hline $\begin{array}{l}\text { Dopuszczony do leczenia } \\
\text { łuszczycy dziecięcej }\end{array}$ & $\mathrm{Nie}$ & Nie & Nie \\
\hline
\end{tabular}

\section{Interleukin- 12 and interleukin-23 inhibitors}

As of now, the only drug of this group used in therapy is ustekinumab, a fully human monoclonal antibody which binds to the p40 subunit of both IL-12 and IL-23. Ustekinumab is highly effective both in treating plaque psoriasis and psoriatic arthritis. Similarly to other biological drugs used in the therapy of psoriasis, ustekinumab is characterised by a favourable safety profile [21].

\section{Interleukin-23 inhibitors}

Based on the suggestions that the inhibition of IL-12 does not bring additional benefits in the treatment of psoriasis, new p19 subunit inhibitors, selectively inhibiting only IL-23, have recently been introduced for therapy.

Three drugs inhibiting the activity of IL-23 (guselkumab, tildrakizumab and risankizumab) are currently used in Poland [23-25]. These drugs show $\mathrm{w}$ trakcie stosowania adalimumabu był niski (poniżej $2 \%)$, porównywalny z grupą placebo [19].

Certolizumab pegol jest fragmentem Fab przeciwciała sprzęgniętym z polietylenoglikolem (PEG). Jak już wspomniano, niedawne badania wskazują, że lek ten praktycznie nie przenika przez łożysko. Powinien być stosowany w okresie ciąży, wyłącznie w sytuacji, jeśli jest to klinicznie uzasadnione. Poza takimi przypadkami rekomenduje się, aby kobiety $\mathrm{w}$ wieku rozrodczym stosowały antykoncepcję $\mathrm{w}$ czasie leczenia i przez co najmniej 5 miesięcy od przyjęcia ostatniej dawki leku.

\section{Leki blokujące interleukinę 17}

Obecnie do leczenia łuszczycy w Europie zarejestrowane zostały dwa przeciwciała monoklonalne blokujące bezpośrednio IL-17A (iksekizumab i sekukinumab) i przeciwciało monoklonalne blokujące receptor dla IL-17 (brodalumab) (tab. 8). Prawdopodobnie wkrótce rejestrację uzyska także bimekizu- 
high efficacy (PASI-75 is achieved by approximately $80-90 \%$, and PASI-90 by about $70 \%$ of patients) and a favourable safety profile (table 9 ).

\section{Combination therapy}

All patients with psoriasis receiving systemic treatment should concurrently use topical drugs, unless contraindications to topical therapy are found. Topical treatment contributes to a faster clinical improvement and helps reduce the dose of the systemic drug necessary to achieve a therapeutic effect. In this mab blokujący IL-17A i IL-17F. Skuteczność leków blokujących IL-17 została potwierdzona w licznych wieloośrodkowych badaniach klinicznych obejmujących populację kilku tysięcy pacjentów [20-22]. Skuteczność terapii rekomendowanymi dawkami inhibitorów IL-17 wynosi po 12-16 tygodniach ok. 76-93\% dla PASI-75, 54-79\% dla PASI-90 oraz 24-44\% dla PASI-100, zgodnie z danymi z ChPL.

Profil bezpieczeństwa tej grupy leków jest korzystny. W trakcie terapii można jednak niekiedy obserwować tendencję do występowania infekcji grzybiczych, przede wszystkim łagodne i umiarkowanie nasilone kandydozy

Table 9. Characteristics of biological interleukin- $12 / 23$ and interleukin-23 inhibitors

\begin{tabular}{|c|c|c|c|c|}
\hline \multirow[t]{2}{*}{ Parameter } & \multirow{2}{*}{$\begin{array}{c}\text { Anti-interleukin- } 12 / 23 \\
\text { agents } \\
\text { Ustekinumab }\end{array}$} & \multicolumn{3}{|c|}{ Anti-interleukin-23 agents } \\
\hline & & Guselkumab & Risankizumab & Tildrakizumab \\
\hline Drug type & $\begin{array}{l}\text { Human IgGI monoclonal } \\
\text { antibody against IL- I 2/23 }\end{array}$ & $\begin{array}{c}\text { Human } \operatorname{lgG} \mid \lambda \\
\text { monoclonal antibody } \\
\text { against IL-23 }\end{array}$ & $\begin{array}{l}\text { Humanised lgGI } \\
\text { monoclonal antibody } \\
\text { against IL-23 }\end{array}$ & $\begin{array}{l}\text { Humanised } \operatorname{lgG} \mid \kappa \\
\text { monoclonal antibody } \\
\text { against IL-23 }\end{array}$ \\
\hline Approved indications & $\begin{array}{l}\text { Plaque psoriasis } \\
\text { Psoriatic arthritis }\end{array}$ & Plaque psoriasis & Plaque psoriasis & Plaque psoriasis \\
\hline $\begin{array}{l}\text { Dosing regimen in } \\
\text { plaque psoriasis }\end{array}$ & $\begin{array}{c}45 \mathrm{mg} \text { (for patients } \\
<100 \mathrm{~kg} \text { ) or } 90 \mathrm{mg} \\
\text { (for patients }>100 \mathrm{~kg} \text { ) at } \\
\text { weeks } 0 \text { and } 4 \text {, followed } \\
\text { by every } 12 \text { weeks }\end{array}$ & $\begin{array}{c}100 \mathrm{mg} \text { at weeks } \\
0 \text { and } 4, \text { followed by } \\
\text { every } 8 \text { weeks }\end{array}$ & $\begin{array}{c}150 \mathrm{mg} \text { at weeks } \\
0 \text { and } 4, \text { followed by } \\
\text { every } 12 \text { weeks }\end{array}$ & $\begin{array}{c}100 \mathrm{mg} \text { at weeks } \\
0 \text { and } 4, \text { followed by } \\
\text { every } 12 \text { weeks }\end{array}$ \\
\hline Route of administration & Subcutaneous & Subcutaneous & Subcutaneous & Subcutaneous \\
\hline $\begin{array}{l}\text { Approved for the } \\
\text { treatment of childhood } \\
\text { psoriasis }\end{array}$ & $\begin{array}{l}\text { Children and adolescents } \\
\text { from the age of } 6 \\
\text { (children and adolescents } \\
<60 \mathrm{~kg} \mathrm{bw} \text { : } \\
0.75 \mathrm{mg} / \mathrm{kg} \mathrm{bw})\end{array}$ & No & No & No \\
\hline
\end{tabular}

Tabela 9. Charakterystyka leków biologicznych blokujących interleukinę I2/23 i interleukinę 23

\begin{tabular}{|c|c|c|c|c|}
\hline \multirow[t]{2}{*}{ Parametr } & \multirow{2}{*}{$\begin{array}{c}\text { Leki blokujące } \\
\text { interleukinę 12/23 } \\
\text { Ustekinumab }\end{array}$} & \multicolumn{3}{|c|}{ Leki blokujące interleukinę 23} \\
\hline & & Guselkumab & Ryzankizumab & Tildrakizumab \\
\hline Typ leku & $\begin{array}{l}\text { Ludzkie przeciwciało } \\
\text { monoklonalne IgGI } \\
\text { przeciwko IL- I 2/23 }\end{array}$ & $\begin{array}{l}\text { Ludzkie przeciwciało } \\
\text { monoklonalne } \operatorname{lgG} \mid \lambda \\
\text { przeciwko IL-23 }\end{array}$ & $\begin{array}{c}\text { Humanizowane } \\
\text { przeciwciało } \\
\text { monoklonalne lgGI } \\
\text { przeciwko IL-23 }\end{array}$ & $\begin{array}{c}\text { Humanizowane } \\
\text { przeciwciało } \\
\text { monoklonalne lgG | } \\
\text { przeciwko IL-23 }\end{array}$ \\
\hline $\begin{array}{l}\text { Wskazanie } \\
\text { rejestracyjne }\end{array}$ & $\begin{array}{c}\text { Łuszczyca plackowata } \\
\text { Łuszczycowe zapalenie } \\
\text { stawów }\end{array}$ & Łuszczyca plackowata & Łuszczyca plackowata & Łuszczyca plackowata \\
\hline $\begin{array}{l}\text { Dawkowanie } \\
\text { w łuszczycy } \\
\text { plackowatej }\end{array}$ & $\begin{array}{c}45 \text { mg (dla pacjentów } \\
<100 \mathrm{~kg} \text { ) lub } 90 \text { mg } \\
\text { (dla pacjentów > } 100 \mathrm{~kg} \text { ) } \\
\text { w tygodniu } 0 \text { i } 4 ., \\
\text { a następnie co } 12 \text { tygodni }\end{array}$ & $\begin{array}{c}100 \text { mg w tygodniach } \\
0 \text { i } 4 . \text {, a następnie co } \\
8 \text { tygodni }\end{array}$ & $\begin{array}{c}\text { I } 50 \text { mg w tygodniach } \\
0 \text { i } 4 ., \text { a następnie co } \\
\text { I } 2 \text { tygodni }\end{array}$ & $\begin{array}{c}100 \text { mg w tygodniach } \\
0 \text { i } 4 ., \text { a następnie co } \\
\text { I } 2 \text { tygodni }\end{array}$ \\
\hline Droga podania & Podskórnie & Podskórnie & Podskórnie & Podskórnie \\
\hline $\begin{array}{l}\text { Dopuszczony do } \\
\text { leczenia łuszczycy } \\
\text { dziecięcej }\end{array}$ & $\begin{array}{l}\text { U dzieci i młodzieży } \\
\text { w wieku od } 6 \text { lat } \\
\text { (u dzieci i młodzieży } \\
\text { < } 60 \text { kg m.c.: } \\
\text { 0,75 mg/kg m.c.) }\end{array}$ & Nie & Nie & Nie \\
\hline
\end{tabular}


way, topical therapy plays a role in limiting the prevalence of adverse reactions.

As regards conventional systemic drugs, no combination therapy (except for re-PUVA - see above) has been formally approved because of lack of safety data for a given combination and the consequent significant increase in the risk of adverse reactions. On the other hand, traditional systemic drugs can be combined with biological treatment in order to enhance the efficacy of therapy, reduce the risk of immunogenicity or improve long-term therapeutic outcome. In such cases, however, patients require closer monitoring on account of a potentially higher risk of infectious complications.

\section{Vaccinations}

In accordance with opinion of many experts and international recommendations (National Psoriasis Foundation Medical Board's recommendations to vaccinate adult patients on systemic immunosuppressive therapy for psoriasis), vaccination against influenza and, if necessary, pneumococcal disease in patients with severe psoriasis should be considered prior to initiating immunosuppressive therapy [26, 27].

\section{CONFLICT OF INTEREST}

Adam Reich - Consultant or Speaker for AbbVie, Bioderma, Celgene, Chema Elektromet, Eli Lilly, Galderma, Janssen, Leo Pharma, Medac, Menlo Therapeutics, Novartis, Pierre-Fabre, Sandoz and Trevi Therapeutics. Principal Investigator or Sub-investigator in clinical trials sponsored by AbbVie, Drug Delivery Solutions Ltd, Galderma, Genentech, Janssen, Kymab Limited, Leo Pharma, Menlo Therapeutics, MetrioPharm, MSD, Novartis, Pfizer and Trevi Therapeutics. Dorota Krasowska - Consultant or Speaker for Eli Lilly, Janssen, Leo Pharma, Novartis, Sanofi-Aventis. Principal Investigator or Sub-investigator in clinical trials sponsored by AbbVie, Leo Pharma, Novartis, Corbus, Galapagos, Principia Biopharma, Baxalta, Anaptys Bio, Pfizer and Boehringer-Ingelheim. Aleksandra Lesiak - Speaker or Advisory board member for AbbVie, Almirall, Eli-Lilly, Janssen, Novartis. Joanna Narbutt - Speaker or Advisory board member for AbbVie, Almirall, Eli-Lilly, Janssen, Novartis. Agnieszka Osmola-Mańkowska - Speaker for Novartis, Lilly, Janssen-Cilag, Leo, Teva, Advisory board member: AbbVie, Lilly, Celgene, Egis, Scholarship from Janssen, AbbVie, Projects for Medac, Leo. Lidia Rudnicka - invited medical lectures by Leo Pharma and Eli Lilly; udział w spotkaniach grup doradczych Leo Pharma, Janssen Pharmaceutical Companies, Pfizer Novartis and UCB. Jacek Szepietowski - Adviso- skóry i błon śluzowych, które wynikają z mechanizmu działania tych leków. W większości poddawały się one standardowemu leczeniu przeciwgrzybiczemu i nie wymagały przerwania terapii przeciwłuszczycowej.

\section{Lek blokujący interleukinę I 2 i interleukinę 23}

Dotychczas z tej grupy leków stosowany był jedynie ustekinumab, w pełni ludzkie przeciwciało monoklonalne, które wiąże się z podjednostką białkową p40 wspólną dla IL-12 i IL-23. Ustekinumab cechuje się dużą skutecznością zarówno w łuszczycy plackowatej, jak i w łuszczycowym zapaleniu stawów. Podobnie jak w przypadku innych leków biologicznych stosowanych w łuszczycy terapia ustekinumabem charakteryzuje się korzystnym profilem bezpieczeństwa [21].

\section{Leki blokujące interleukinę 23}

Z uwagi na sugestie, że blokada IL-12 nie przynosi dodatkowych korzyści w łuszczycy, niedawno do lecznictwa wprowadzono nowe leki blokujące podjednostkę p19, selektywnie blokujące jedynie IL-23.

Obecnie w Polsce stosowane są trzy leki hamujące działanie IL-23: guselkumab, ryzankizumab i tildrakizumab [23-25]. Leki wykazują dużą skuteczność (PASI75 uzyskuje około 80-90\% chorych, a PASI-90 około 70\%) i korzystny profil bezpieczeństwa (tab. 9).

\section{Leczenie skojarzone}

Pacjenci chorzy na łuszczycę otrzymujący leczenie ogólne mogą jednocześnie stosować leki miejscowe. Terapia miejscowa przyczynia się do szybszego uzyskania poprawy klinicznej oraz może powodować zmniejszenie dawki leku ogólnego, jaka jest niezbędna do uzyskania efektu terapeutycznego.

W przypadku klasycznych leków ogólnych żadna terapia skojarzona (z wyjątkiem Re-PUVA) nie została formalnie zaaprobowana przez ekspertów $\mathrm{z}$ uwagi na brak danych dotyczących bezpieczeństwa danej kombinacji i związane $\mathrm{z}$ tym znacząco zwiększone ryzyko wystąpienia działań niepożądanych. Tradycyjne leki ogólne mogą być natomiast łączone z leczeniem biologicznym w celu zwiększenia skuteczności terapii, zmniejszenia ryzyka immunogenności lub poprawy długotrwałych wyników. W takich przypadkach pacjenci wymagają ściślejszej kontroli ze względu na potencjalnie większe ryzyko wystąpienia powikłań infekcyjnych.

\section{Szczepienia ochronne}

Zgodnie z zaleceniami wielu ekspertów i rekomendacjami międzynarodowymi (National Psoriasis Foundation Medical Board's recommendations to vaccinate adult patients on systemic immunosuppressive therapy for psoriasis) wskazane jest szczepienie przeciwko grypie i w razie uznania konieczności przeciwko pneumoko- 
ry Board Member: AbbVie, Leo Pharma, Novartis, Pierre-Fabre, Menlo Therapeutics, Sienna Biopharmaceuticals, Trevi, Sanofi-Genzyme. Speaker: AbbVie, Leo Pharma, Novartis, Janssen, Sunfarm, EliLilly, Berlin Chemie Mennarini, Sanofi-Genzyme. Investigator: AbbVie, Novartis, Menlo Therapeutics, Trevi, Janssen, Merck, Regeneron, Amgen, Boehringer Ingelheim, Galapagos, InflaRX, Pfizer, UCB, Incyte, Helm. Others authors declare no conflict of interest. kom u chorych z ciężkim przebiegiem łuszczycy, przed włączeniem leczenia immunosupresyjnego [26, 27].

Celem przedstawionych rekomendacji jest wsparcie lekarzy w optymalizacji opieki nad chorymi na łuszczycę i zapewnienie pacjentom odpowiedniej pomocy lekarskiej, dostosowanej do ciężkości choroby i dostępnych możliwości terapeutycznych. Należy zaznaczyć, że każdorazowo lekarz prowadzący leczenie musi dostosować swoje decyzje diagnostyczne i terapeutyczne indywidualnie do bieżących potrzeb chorego, uwzględniając jego aktualny stan kliniczny, a także opierając się na bieżących doniesieniach naukowych.

\section{KONFLIKT INTERESÓW}

Adam Reich - konsultant lub wykładowca dla AbbVie, Bioderma, Celgene, Chema Elektromet, Eli Lilly, Galderma, Janssen, Leo Pharma, Medac, Menlo Therapeutics, Novartis, Pierre-Fabre, Sandoz oraz Trevi Therapeutics. Główny badacz lub współbadacz w badaniach klinicznych sponsorowanych przez AbbVie, Drug Delivery Solutions Ltd, Galderma, Genentech, Janssen, Kymab Limited, Leo Pharma, Menlo Therapeutics, MetrioPharm, MSD, Novartis, Pfizer oraz Trevi Therapeutics. Dorota Krasowska konsultant lub wykładowca dla Eli Lilly, Janssen, Leo Pharma, Novartis, Sanofi-Aventis. Główny badacz lub współbadacz w badaniach klinicznych sponsorowanych przez AbbVie, Leo Pharma, Novartis, Corbus, Galapagos, Principia Biopharma, Baxalta, Anaptys Bio, Pfizer and Boehringer-Ingelheim. Aleksandra Lesiak - wykładowca i/lub członek komitetów doradczych dla AbbVie, Almirall, Eli-Lilly, Janssen, Novartis. Joanna Narbutt - wykładowca i/lub członek komitetów doradczych dla AbbVie, Almirall, Eli-Lilly, Janssen, Novartis. Agnieszka Osmola-Mańkowska - wykładowca dla Novartis, Lilly, Janssen-Cilag, Leo, Teva, udział w Advisory board AbbVie, Lilly, Cellgene, Egis, stypendium Janssen, AbbVie, projekty Medac, Leo. Lidia Rudnicka - wykłady medyczne na zaproszenie Leo Pharma oraz Eli Lilly; udział w spotkaniach grup doradczych Leo Pharma, Janssen Pharmaceutical Companies, Novartis, Pfizer i UCB. Jacek Szepietowski - członek komitetów doradczych: AbbVie, Leo Pharma, Novartis, Pfizer i Pierre-Fabre, Menlo Therapeutics, Sienna Biopharmaceuticals, Trevi, Sanofi-Genzyme. Wygłaszający wykłady: AbbVie, Leo Pharma, Novartis, Janssen, Sunfarm, Eli-Lilly, Berlin Chemie Mennarini, Sanofi-Genzyme. Badacz: AbbVie, Novartis, Menlo Therapeutics, Trevi, Janssen, Merck, Regeneron, Amgen, Boehringer Ingelheim, Galapagos, InflaRX, Pfizer, UCB, Incyte, Helm. Pozostali autorzy nie zgłaszają konfliktu interesów. 


\section{References}

\section{Piśmiennictwo}

1. Norsgaard H., Kurdykowski S., Descargues P., Gonzalez T., Marstrand T., Dünstl G., et al.: Calcipotriol counteracts betamethasone-induced decrease in extracellular matrix components related to skin atrophy. Arch Dermatol Res 2014, 306, 719-729.

2. Reich A., Adamski Z., Chodorowska G., Kaszuba A., Krasowska D., Lesiak A., et al.: Łuszczyca. Rekomendacje diagnostyczno-terapeutyczne Polskiego Towarzystwa Dermatologicznego. Część I: łuszczyca łagodna. Przegl Dermatol 2018, 105, 225-243.

3. Kragballe K., Austad J., Barnes L., Bibby A., de la Brassinne M., Cambazard F., et al.: A 52-week randomized safety study of a calcipotriol/ betamethasone dipropionate two-compound product (Dovobet/Daivobet/Taclonex) in the treatment of psoriasis vulgaris. Br J Dermatol 2006, 154, 1155-1160.

4. Paul C., Stein Gold L., Cambazard F., Kalb R.E., Lowson D., Bang B., et al.: Calcipotriol plus betamethasone dipropionate aerosol foam provides superior efficacy vs. gel in patients with psoriasis vulgaris: randomized, controlled PSO-ABLE study. J Eur Acad Dermatol Venereol 2017, 31, 119-126.

5. Lebwohl M., Freeman A., Chapman M.S., Feldman S., Hartle J., Henning A.: Proven efficacy of tacrolimus for facial and intertriginous psoriasis. Arch Dermatol 2005, 141, 1154

6. Chen X., Yang M., Cheng Y., Liu G.J., Zhang M.: Narrow-band ultraviolet B phototherapy versus broad-band ultraviolet B or psoralen-ultraviolet A photochemotherapy for psoriasis. Cochrane Database Syst Rev 2013, 10, CD009481.

7. Elmets C.A., Lim H.W., Stoff B., Connor C., Cordoro K.M., Lebwohl M., et al.: Joint American Academy of Dermatology-National Psoriasis Foundation guidelines of care for the management and treatment of psoriasis with phototherapy. J Am Acad Dermatol 2019, 81, 775-804

8. Placek W., Kaszuba A., Lesiak A., Maj J., Narbutt J., Osmola-Mańkowska A., et al.: Fototerapia i fotochemoterapia w dermatologii. Rekomendacje Polskiego Towarzystwa Dermatologicznego. Przegl Dermatol 2019, 106, 237-256.

9. Schmitt J., Rosumeck S., Thomaschewski G., Sporbeck B., Haufe E., Nast A.: Efficacy and safety of systemic treatments for moderate-to-severe psoriasis: meta-analysis of randomized controlled trials. Br J Dermatol 2014, 170, 274-303.

10. Dogra S., Krishna V., Kanwar A.J.: Efficacy and safety of systemic methotrexate in two fixed doses of $10 \mathrm{mg}$ or $25 \mathrm{mg}$ orally once weekly in adult patients with severe plaque-type psoriasis: a prospective, randomized, double-blind, dose-ranging study. Clin Exp Dermatol 2012, 37, 729-334.

11. Baran W., Batycka-Baran A., Zychowska M., Bieniek A., Szepietowski J.C.: Folate supplementation reduces the side effects of methotrexate therapy for psoriasis. Expert Opin Drug Saf 2014, 13, 1015-1021.

12. Nast A., Gisondi P., Ormerod A.D., Saiag P., Smith C., Spuls P.I., et al.: European S3-Guidelines on the systemic treatment of psoriasis vulgaris - Update 2015 - Short version - EDF in cooperation with EADV and IPC. J Eur Acad Dermatol Venereol 2015, 29, 2277-2294.

13. Naldi L.: Malignancy concerns with psoriasis treatments using phototherapy, methotrexate, cyclosporin, and biologics: facts and controversies. Clin Dermatol 2010, 28, 88-92.

14. Menon K., Van Voorhees A.S., Bebo B.F. Jr, Gladman D.D., Hsu S., Kalb R.E., et al.: Psoriasis in patients with HIV infection: from the medical board of the National Psoriasis Foundation. J Am Acad Dermatol 2010, 62, 291-299.

15. Schafer P.H., Chen P., Fang L., Wang A., Chopra R.: The pharmacodynamic impact of apremilast, an oral phosphodiesterase 4 inhibitor, on circulating levels of inflammatory biomarkers in patients with psoriatic arthritis: substudy results from a phase III, randomized, placebo-controlled trial (PALACE 1). J Immunol Res 2015, 2015, 906349.

16. Kavanaugh A., Mease P.J., Gomez-Reino J.J., Adebajo A.O., Wollenhaupt J., Gladman D.D., et al.: Treatment of psoriatic arthritis in a phase 3 randomised, placebo-controlled trial with apremilast, an oral phosphodiesterase 4 inhibitor. Ann Rheum Dis 2014, 73, 1020-1026.

17. Mrowietz U., Szepietowski J.C., Loewe R., van de Kerkhof P., Lamarca R., Ocker W.G., et al.: Efficacy and safety of LAS41008 (dimethyl fumarate) in adults with moderate-to-severe chronic plaque psoriasis: a randomized, double-blind, Fumaderm $\left({ }^{\circledR}\right)$ and placebo-controlled trial (BRIDGE). Br J Dermatol 2017, 176, 615-623.

18. Mariette X., Förger F., Abraham B., Flynn A.D., Moltó A., Flipo R.M., e al.: Lack of placental transfer of certolizumab pegol during pregnancy: results from CRIB, a prospective, postmarketing, pharmacokinetic study. Ann Rheum Dis 2018, 77, 228233.

19. Menter A., Tyring S.K., Gordon K., Kimball A.B., Leonardi C.L., Langley R.G., et al.: Adalimumab therapy for moderate to severe psoriasis: a randomized controlled phase III trial. J Am Acad Dermatol 2007, 58, 106-115.

20. Gordon K.B., Blauvelt A., Papp K.A., Langley R.G., Luger T., Ohtsuki M., et al.: Phase 3 trials of ixekizumab in moderate-to-severe plaque psoriasis. N Engl J Med 2016, 375, 345-356.

21. Lebwohl M., Strober B., Menter A., Gordon K., Weglowska J., Puig L., et al.: Phase 3 studies comparing brodalumab with ustekinumab in psoriasis. N Engl J Med 2015, 373, 1318-1328.

22. McInnes I.B., Mease P.J., Kirkham B., Kavanaugh A., Ritchlin C.T., Rahman P., et al.: Secukinumab, a human anti-interleukin-17A monoclonal antibody, in patients with psoriatic arthritis (FUTURE 2): a randomised, double-blind, placebo-controlled, phase 3 trial. Lancet 2015, 386, 1137-1146.

23. Papp K.A., Blauvelt A., Bukhalo M., Gooderham M., Krueger J.G., Lacour J.P., et al.: Risankizumab versus ustekinumab for moderate-to-severe plaque psoriasis. N Engl J Med 2017, 376, 1551-1560.

24. Reich K., Armstrong A.W., Langley R.G., Flavin S., Randazzo B., Li S., et al.: Guselkumab versus secukinumab for the treatment of moderate-to-severe psoriasis (ECLIPSE): results from a phase 3, randomized controlled trial. Lancet 2019, 394, 831-839.

25. Reich K., Papp K.A., Blauvelt A., Tyring S.K., Sinclair R., Thaçi D., et al.: Tildrakizumab versus placebo or etanercept for chronic plaque psoriasis (reSURFACE 1 and reSURFACE 2): results from two randomised controlled, phase 3 trials. Lancet $2017,390,276-288$. 
26. Singh J.A., Guyatt G., Ogdie A., Gladman D.D., Deal C., Deodhar A., et al.: 2018 American College of Rheumatology/ National Psoriasis Foundation Guideline for the Treatment of Psoriatic Arthritis. Arthritis Care Res (Hoboken) 2019, 71, 2-29. 27. Wine-Lee L., Keller S.C., Wilck M.B., Gluckman S.J., Van Voorhees A.S.: From the Medical Board of the National Psoriasis Foundation: vaccination in adult patients on systemic therapy for psoriasis. J Am Acad Dermatol 2013, 69, 1003-1013.

Received: 19.01 .2020

Accepted: 15.03 .2020

Otrzymano: $19.01 .2020 \mathrm{r}$

Zaakceptowano: $15.03 .2020 \mathrm{r}$.

How to cite this article

Reich A., Adamski Z., Chodorowska G., Kaszuba A., Krasowska D., Lesiak A., Maj J., Narbutt J., Osmola-Mańkowska A.J., Owczarczyk-Saczonek A., Owczarek W., Placek W.J., Rudnicka L., Szepietowski J.: Psoriasis. Diagnostic and therapeutic recommendations of the Polish Dermatological Society. Part 2. Dermatol Rev/Przegl Dermatol 2020, 107, 110-137. DOI: https://doi.org/10.5114/dr.2020.95259. 